\title{
Contrasting isotopic sources (Sm-Nd) of Late Ediacaran series in the Iberian Massif: Implications for the Central Iberian-Ossa Morena boundary
}

\author{
Esther Rojo-Pérez ${ }^{\mathrm{a}, *}$, Ricardo Arenas ${ }^{\mathrm{a}}$, José M. Fuenlabrada ${ }^{\mathrm{b}}$, Sonia Sánchez \\ Martínez ${ }^{a}$, Luis Miguel Martín Parra ${ }^{c}$, Jerónimo Matas ${ }^{c}$, Agustín P. Pieren ${ }^{d}$, Rubén \\ Díez Fernández ${ }^{\mathrm{d}}$ \\ a Departamento de Mineralogía y Petrología e Instituto de Geociencias (UCM, CSIC), Universidad Complutense, 28040 Madrid, Spain
b Unidad de Geocronología, Universidad Complutense, 28040 Madrid, Spain
${ }^{c}$ Instituto Geológico y Minero de España, 28760 Tres Cantos, Madrid, Spain
${ }^{d}$ Departamento de Geodinámica, Estratigrafía y Paleontología, Universidad Complutense, 28040 Madrid, Spain
}

\section{A B S T R A C T}

In the Iberian Massif, westernmost sector of the Variscan Orogen, the nature of the boundary between the Central Iberian Zone and the Ossa Morena Complex has been largely discussed. Peri-Gondwanan Ediacaran series similar in age (c. $565 \mathrm{Ma}$ ) but different in composition occur at both sides of that boundary. The Lower Alcudian Series (Central Iberian Zone) is located to the north, while the Serie Negra (Ossa-Morena Complex) can be found to the south of the boundary. Major and trace element compositions and Sm-Nd isotopic systematics of siliciclastic rocks from both series suggest a common active margin setting for their deposition, the Serie Negra likely occupying a more external (fore-arc) position within the arc-system relative to the Lower Alcudian Series, which would have been deposited within a large back-arc domain. TDM ages for these two series are notably different, yielding values of 1421-2040 Ma and 1256-1334 Ma for the Serie Negra and Lower Alcudian, respectively. These values suggest higher input from old cratonic sources in the Ossa Morena Complex, with probable participation of the West African Craton, which would be less prominent in the Central Iberia Zone. The whole data set indicate deposition of the Ediacaran series in separated basins, probably far away from each other along/across the margin of Gondwana. Current juxtaposition of these basins is explained by Variscan and probably also pre-Variscan tectonics. Similar conclusions could be also be extended to other similar boundaries in the Variscan Orogen.

Introduction

The Variscan Orogen resulted from the collision between Gondwana and Laurussia, during the main stages of the Pangea assembly in Devonian-Carboniferous times (Matte, 2001; Martínez Catalán, 2011; Arenas et al., 2014; Díez Fernández et al., 2016). The Iberian Massif represents the southwestern European branch of this orogen and con- tains the suture of the collision and an excellent record of the strati- graphic series deposited during the Ediacaran and Paleozoic in the continental margin of Gondwana (Fig. 1). These series are distributed through diverse geotectonic zones (Fig. 1), each of which characterized by a stratigraphic and tectonic record indicative of basins developed at different paleogeographic positions along the continental paleomargin. The juxtaposition of formerly distant paleogeographic domains of Gondwana is, in part, a consequence of the Variscan convergence, and it is being actively investigated by means of provenance analysis of sedimentary series in order to reconstruct the original position of pa- leobasins in the Gondwana margin (Díez Fernández et al., 2010; Fernández-Suárez et al., 2014; Albert et al., 2015a).

In the SW of the Iberian Massif, the nature of the boundary between the autochthonous (Central Iberian Zone) and the allochthonous do- mains (Ossa-Morena Complex) (Figs. 1 and 2) is subject to discussion. From a paleogeographic point of view, sections of the margin of Gondwana that show equivalent sedimentary record to the Central Iberian Zone or to the Ossa-Morena Complex are distributed along the Variscan orogen (Fig. 1). Therefore, advances in the understanding of 


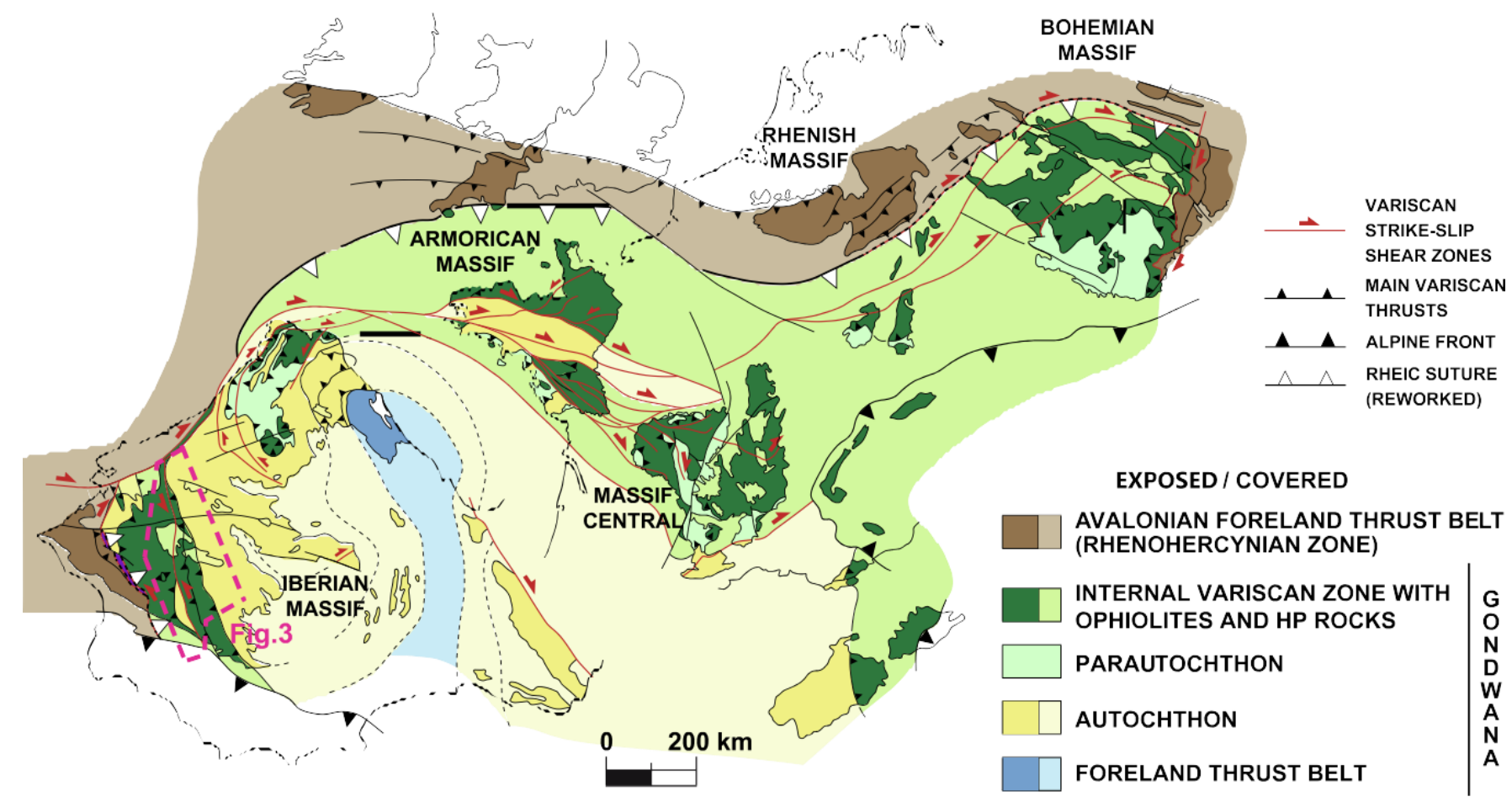

Fig. 1. Zonation of the Variscan Orogen (Díez Fernández and Arenas, 2015; Arenas et al., 2016b). Based in Franke (1989), Lefort (1989), Neuman and Max (1989) and Martínez Catalán (2011). Location of the geological map presented in Fig. 3 is shown.

such boundary in Iberia contribute to the understanding of equivalent boundaries throughout the Variscan orogen.

The boundary between the Central Iberian Zone and the Ossa- Morena Complex has been interpreted as a stratigraphic transition zone (Martínez Poyatos, 2002), or as an extensional detachment (Martín Parra et al., 2006), or as the remnant of a major thrust (currently re- worked as an extensional detachment), which would have emplaced northward the Ossa-Morena Complex onto the Central Iberian Zone (Díez Fernández and Arenas, 2015). On the other hand, U-Pb detrital zircon data suggest that during the Ediacaran and Early Paleozoic the basins of the Central Iberian Zone were located in a more eastern po- sition along the Gondwanan margin relative to the series from the Ossa- Morena Complex, although its specific location between the West African Craton, the Tuareg Shield and the Sahara Metacraton is very uncertain (Bea et al., 2010; Díez Fernández et al., 2010; Talavera et al., 2012; Fernández-Suárez et al., 2014; Shaw et al., 2014; Albert et al., 2015a; Cambeses et al., 2017). However, the use of isotopic tracers based on whole rock geochemistry, such as the Sm-Nd methodology, is yet to be exploited as a tool to constrain the nature of the Central Iberian Zone and Ossa-Morena Complex boundary, since the isotopic sources of coeval series at both sides of it have not been compared. It is important to point out that until now, there are not appropriate data- bases to make comparisons with the section of the Gondwanan margin preserved in North Africa, since most of the Sm-Nd available data there have been obtained in granitic rocks (Bea et al., 2010). The isotopic sources of those granitoids indicate large isotopic mixing, with high input of juvenile material (Linnemann et al., 2014; Albert et al., 2015a,b), making very difficult to use them as precise tracers of isotopic sources for a specific age. Therefore, only the investigation of the iso- topic sources associated with siliciclastic sedimentary series allows a confident time-resolved comparison between different crustal sectors.

This work presents a comparison of whole rock geochemical data of coeval Ediacaran siliciclastic series, located at both sides of the Central Iberian Zone - Ossa-Morena Complex boundary, which have been tra- ditionally referred to as Lower Alcudian Series and Serie Negra, re- spectively. For this purpose, we have used published major and trace 
elements data and Sm-Nd isotopic data of the Lower Alcudian Series (Fuenlabrada et al., 2016) and a set of new whole rock data from the Serie Negra obtained in the same laboratories and following the same methodology. The main objective is to discuss on the basis of geo- chemical data whether the Ediacaran series at each side of the afore- mentioned boundary were deposited in the same or in separate sedi- mentary basins. The comparison is established for very close domains of both regions, the southernmost sector of Central Iberian Zone and the northernmost of Ossa-Morena Complex, designated as the Obejo-Val- sequillo Domain. If these Iberian Ediacaran series were located in an initial same paleogeographic area, the proximity of both series would be consistent with the presence of similar Sm-Nd isotopic sources and thus, a deposition in a single sedimentary basin.

The investigation of the tectonic setting and isotopic sources of ancient siliciclastic series, is in general possible using major and trace elements geochemistry and Sm-Nd systematics (McLennan et al., 1990; McLennan and Hemming, 1992; Taylor and McLennan, 1985). In the Iberian Massif, these methodologies have been applied to siliciclastic series laid down during the Ediacaran-Early Cambrian transition, de- posited in a magmatic arc setting in different positions along the African margin of Gondwana (Ugidos et al., 2003; Fuenlabrada et al., 2010, 2012 , 2016; Díez Fernández et al., 2017).

\section{Geological setting}

In the southern sector of the Central Iberian Zone, the Ediacaran siliciclastic series are part of the so-called Schist and Greywacke Complex (Carrington da Costa, 1950; Ovtracht and Tamain, 1970). This group includes Ediacaran turbidites (Lower Unit or Lower Alcudian; San José et al., 1990), outcropping over the cores of the Alcudia and the Centro-Extremeño anticlines (Fig. 3), and Cambrian pelitic sequences (uppermost part of the Upper Unit or Upper Alcudian, Pusa Shales) (Rodríguez Alonso et al., 2004). The northern exposures of the Ossa- Morena Complex are referred to as the Obejo-Valsequillo Domain (Apalategui and Pérez-Lorente, 1983), and the Ediacaran siliciclastic series in that area are known as Serie Negra (Black Series; Carvalhosa, 


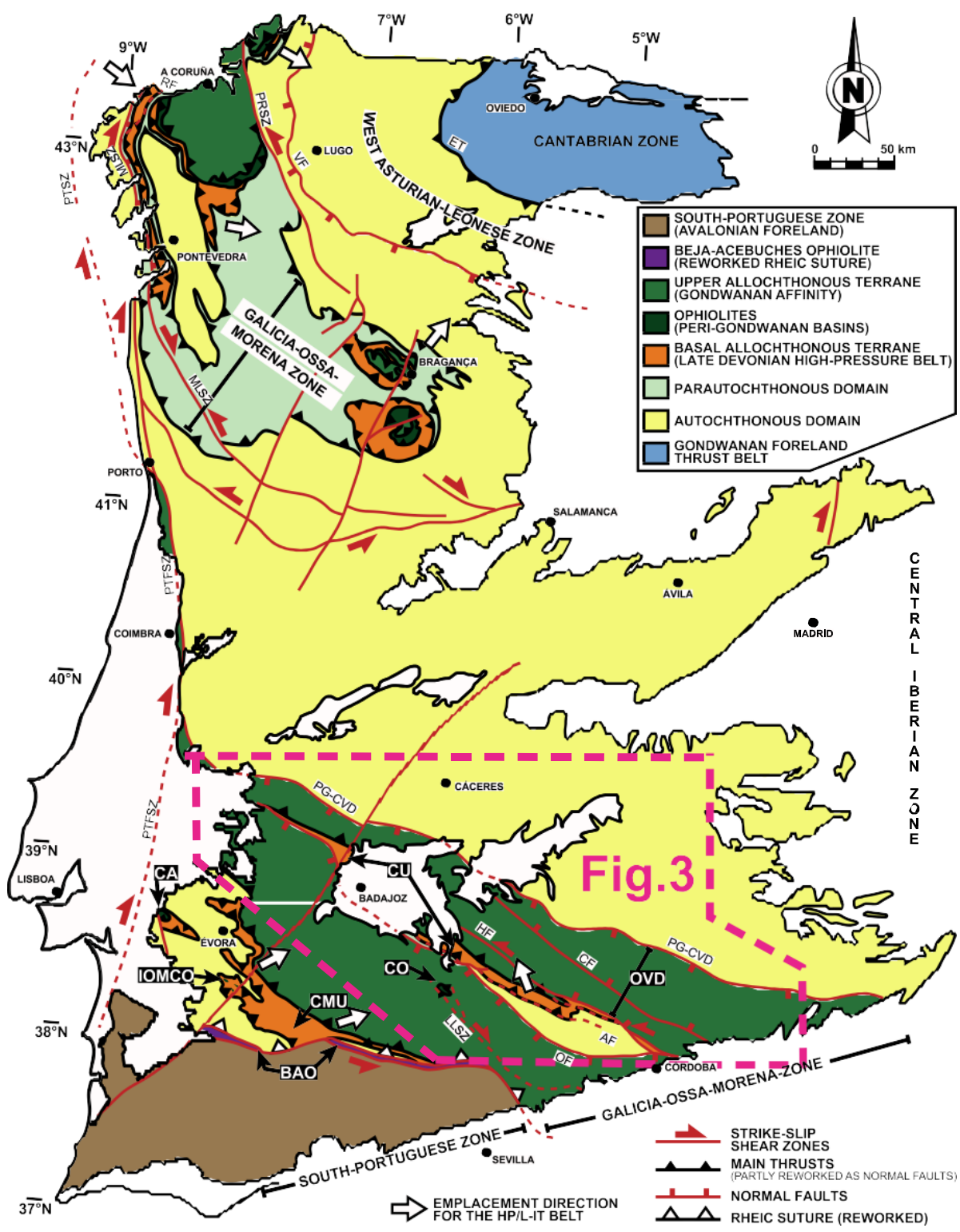

Fig. 2. Geological map of the Iberian Massif showing the distribution of the allochthonous terranes in NW and SW Iberia (Díez Fernández and Arenas, 2015). Abbreviations: AF, Azuaga Fault; BAO, Beja-Acebuches Ophiolite; CA, Carvalhal Amphibolites; CF, Canaleja Fault; $\mathrm{CMU}$, Cubito-Moura Unit; CO, Calzadilla Ophiolite; CU, Central Unit; ET, Espina Thrust; HF, Hornachos Fault; IOMCO, Internal Ossa- Morena Complex Ophiolites; LLF, Llanos Fault; MLF, MalpicaLamego Fault; OF, Onza Fault; OVD, Obejo Valsequillo Domain; PG-CVD, Puente Génave-Castelo de Vide Detachment; PRF, Palas de Rei Fault; PTF, Porto-Tomar Fault; RF, Riás Fault; VF, Viveiro Fault. Location of the geological map presented in Fig. 3 is shown.

1965) (Fig. 3).

\subsection{Stratigraphic record of the Ediacaran series}

The Ediacaran series of the Schist and Greywacke Complex are di- vided in two groups: Lower Alcudian and Upper Alcudian (Redlin, 1955; Ovtracht and Tamain, 1970; Pieren, 2000) (Fig. 3). The Lower Alcudian is composed of a monotonous succession of turbidites, sub- divided from bottom to top into three formations: (1) shales and greywackes of the Coronada Formation, (2) greywackes, micro- conglomerates and shales of the Santa María del Zújar Formation, and

(3) shales, diamictites and greywackes of the Orellana Formation (Pieren, 2000). The minimum thickness of the Lower Alcudian in the southern boundary of the Central Iberian Zone is $6000 \mathrm{~m}$, since its bottom remains unexposed (Pieren, 2000) (Figs. 3 and 4).

The maximum depositional age of the Lower Alcudian has been recently calculated at c. $565 \pm 4 \mathrm{Ma}$ using U-Pb geochronology in detrital zircons (Talavera et al., 2015; Linnemann et al., 2017). This age is equivalent to the age proposed for this sequence by means of pa- leontologic and stratigraphic evidence (Pieren, 2000). This sequence is unconformably overlain by the Upper Alcudian (Figs. 3 and 4), which is thinner and also includes layers of conglomerates and limenstones 
(Pieren, 2000). The geochemistry of the Lower Alcudian siliciclastic rocks (metagreywackes) in the southern sector of the Central Iberian Zone has been recently studied by Fuenlabrada et al. (2016).

The oldest sedimentary series in the Obejo-Valsequillo Domain (Ossa-Morena Complex) is the Serie Negra (Carvalhosa, 1965) (Fig. 3). Although a precise separation is usually complicated in sectors affected by intense deformation and metamorphism, this series has been divided into two formations, from bottom to top: the Montemolín Formation and the Tentudía Formation (Eguíluz, 1988). The Montemolín Forma- tion is composed by metagreywackes, metasandstones, schists, micas- chists, quartzschists and black quartzites, with levels of amphibolites and amphibolic gneisses (Fig. 4). The precise age of this series is un- known, but its maximum depositional age has been estimated at c. $590 \mathrm{Ma}$ (U-Pb geochronology in detrital zircons; Ordóñez Casado, 1998). The Tentudía Formation is composed by metasandstones, vol- canogenic metagreywackes, slates and phyllites, black quartzites, me- tacherts and layers of micaschists and limestones (Fig. 4). Its maximum depositional age has been calculated at c. 565-541 Ma (U-Pb geochro- nology in detrital zircons; Schäfer et al., 1993; Linnemann et al., 2008; Pereira, 2015). It is considered that, with the exception of the Mérida Massif, the Serie Negra exposed in the Obejo-Valsequillo Domain cor- responds to the upper part of the Tentudía Formation (Bandrés, 2001). 


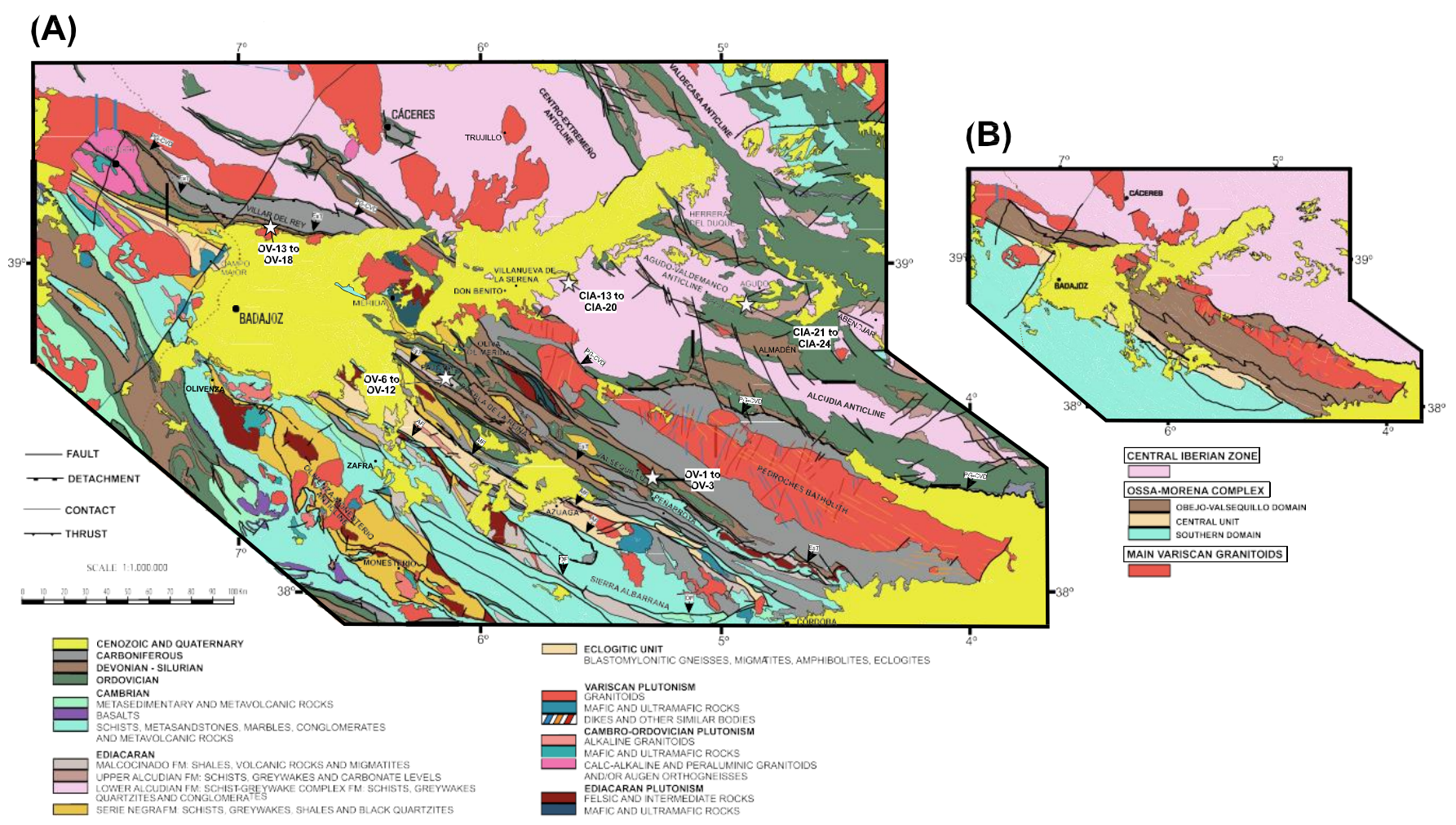

Fig. 3. (A) Geological map of the Central Iberian Zone - Ossa-Morena Complex boundary. (B) Sketch showing the distribution of the main units around this boundary. Based on the 1:1.000.000 geological map of Spain and Portugal (IGME, 2014). AF, Azuaga Fault; EsT, Espiel thrust; PG-CVD, Puente Génave - Castelo de Vide detachment. OV and CIA stars represent the sampling locations in the Obejo-Valsequillo Domain (Serie Negra) and Central Iberian Zone (Lower Alcudian Series), respectively.

Those particular levels are usually characterized by low strain and lower metamorphic grade than those in the Mérida Massif. Overlying these metasedimentary rocks, the unconformable Malcocinado Forma- tion (Fricke, 1941) consists of andesitic tuffs, rhyolites, phyllites, me- tasandstones, metagreywackes and polygenic conglomerates with pebbles of the Serie Negra (Pereira et al., 2006; Cambeses et al., 2017). The age of the Malcocinado Formation probably crosses the Ediacaran- Cambrian boundary (Pereira, 2015). The Torreárboles Formation is considered to be the lowest unconformable Cambrian series (Liñán, 1984). It is constituted by fluvial to shallow marine shelf deposits with slates, metasandstones, metaconglomerates and metabreccias, with a maximum depositional age within the range c. 567-532 Ma (Linnemann et al., 2008; Pereira et al., 2011).

The Ediacaran and Early-Middle Cambrian series of the Ossa- Morena Complex were intruded by extensive igneous rocks ranging in age from c. 600 to $470 \mathrm{Ma}$. This magmatism affected the Gondwanan margin allegedly during a transition from a subduction-related setting (Ediacaran-Early Cambrian) to a rifting context (Middle Cambrian- Early Ordovician) (Sánchez-García et al., 2003, 2013; Linnemann et al., 2008; Pereira et al., 2012; Díez Fernández et al., 2015). The oldest ig- neous rocks of the Serie Negra are mafic in composition and are dated at c. 610-585 Ma (U$\mathrm{Pb}$ in zircons; Sánchez-Lorda et al., 2016). Boni- nitic mafic rocks of the Calzadilla Ophiolite were dated at c. 600 $\mathrm{Ma}$ (U- Pb in zircons; Arenas et al., 2018), and appear imbricated with lower members of the Serie Negra. The geochemistry of those mafic rocks suggests a fore-arc setting for their genesis, a context that can also be extended to at least part of the basin where the Serie Negra was de- posited (Arenas et al., 2018). Palinspastic restoration of Variscan structures in the Iberian Massif places the Central Iberian Zone in a paleogeographic position further inland into Gondwana relative to the Ossa-Morena Complex (Figs. 1 and 2; Díez Fernández et al., 2016), thus suggesting that the deposition of the Lower Alcudian Series took place in a back-arc setting (e.g., Rodríguez-Alonso et al., 2004; Orejana et al.,2015). 


\section{Major and trace elements geochemistry}

\subsection{Methodology}

Sixteen new samples of siliciclastic rocks (mainly metagreywackes) from the Serie Negra were collected in the Obejo-Valsequillo Domain outside the Mérida Massif (Fig. 3). All of them show low to moderate strain, low-grade metamorphism, and correspond to typical facies of the upper levels of the Tentudía Formation (Bandrés, 2001). Three of the metagreywacke samples (OV-1 to OV-3) were collected near Valsequillo village (UTM $30 / 301.796 / 4.250 .980$ ), in a series composed by thin layers of metagreywackes alternating with slates and intruded by the Ediacaran Valsequillo metagranitoid (Bandrés, 2001). Seven samples of rhythmic metagreywackes (OV-6 to OV-12) were collected in a section where sedimentary structures (Bouma sequences) are well preserved, near Palomas village (UTM 30/750.540/4.285.214). The last six sam- ples (OV-13 to OV-16) were collected near Villar del Rey village (UTM 30/685.463/4.333.499), in a section formed by layers of homogeneous fine-grained metagreywackes variably strained. All these samples have been compared with the 12 samples of metagreywackes from the Lower Alcudian, which were previously studied by Fuenlabrada et al. (2016). The later would be the samples CIA-13 to CIA-20 (UTM 30/273.270/ 4.316.456) and CIA-21 to CIA-24 (UTM 30/327.349/4.315.193) (Fig. 3).

The new 16 samples were analyzed for their whole-rock geochem- ical composition of major and trace elements and for their Sm-Nd iso- topes. Major and trace element analyses were performed in the ActLabs laboratories, Ontario (Canada). Crushing and powdering of the samples were performed at Universidad Complutense de Madrid. Lithium me- taborate/tetraborate was used for fusion and the elements were mea- sured by inductively coupled plasma mass spectrometry (ICP-MS). The 

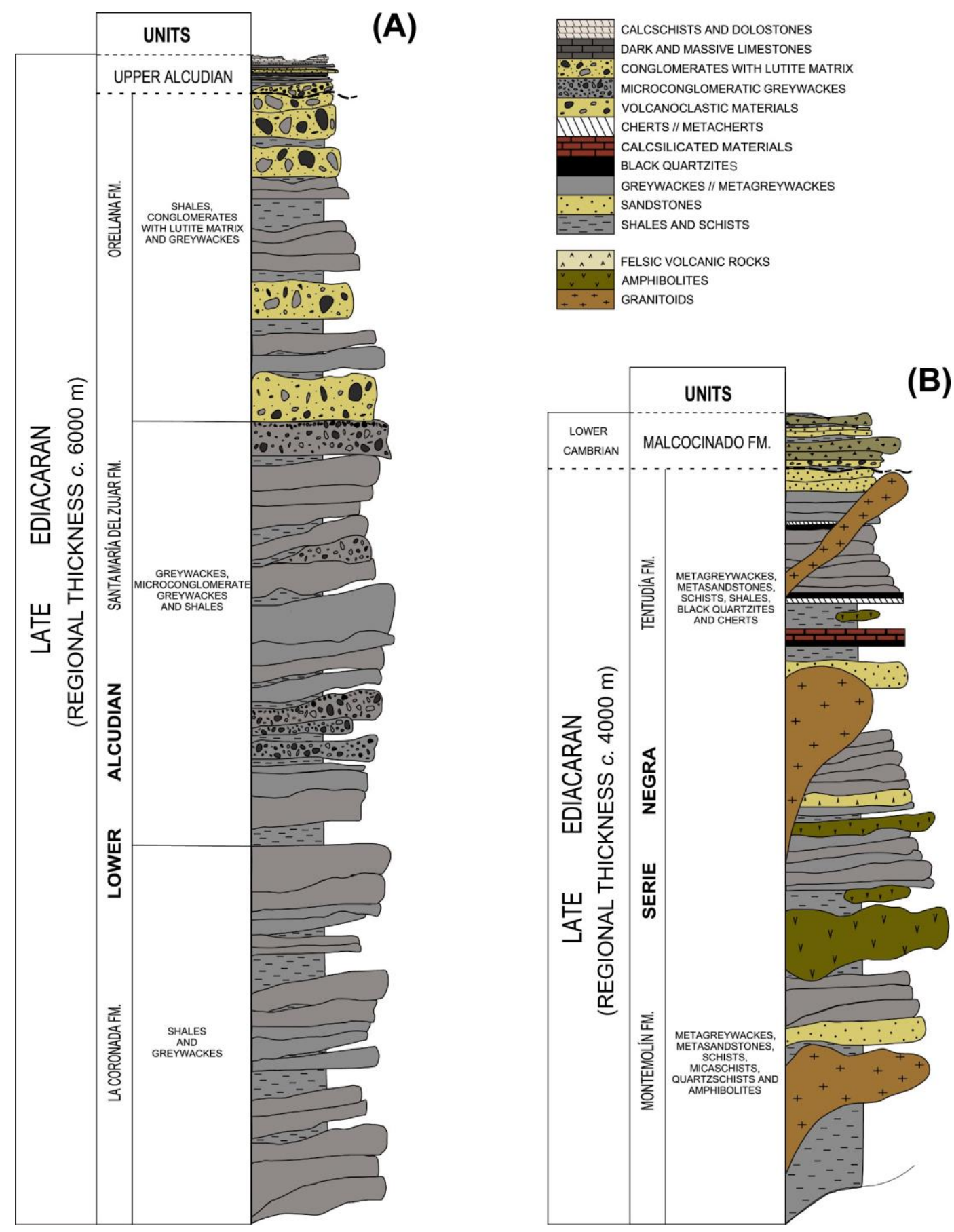

Fig. 4. Schematic stratigraphic columns of the Late Ediacaran series. (A) Lower Alcudian Series from the southern part of the Central Iberian Zone. (B) Serie Negra Group from the Obejo Valsequillo Domain (Ossa-Morena Complex).

quality of the analyses is high and the general precision is calculated at $\sim 0.01 \%$, with higher precision $(\sim 0.001 \%)$ for $\mathrm{MnO}$ and $\mathrm{TiO} 2$. The results of the analyses are included in Table 1 and plotted into the diagrams presented in Fig. 5.

The geochemistry of major and trace elements in siliciclastic rocks is widely used to understand their nature and alteration degree, as well as to track provenance sources and tectonic setting for sedimentary basins (Holland, 1978; Nesbitt and Young, 1982; Taylor and McLennan, 1985; Bhatia, 1983; Bhatia and Crook, 1986; Herron, 1988; Floyd et al., 1991). Elements with a particularly stable behaviour (REE, Th, Cr, Co, Nb, Ti, Sc, Zr, Y, Hf) provide a basis for interpreting the conditions under which sedimentation of the Ediacaran Iberian series took place. 


\subsection{Results}

Samples collected in the Obejo-Valsequillo Domain (Serie Negra) display quite homogenous contents in major elements (Table 1). No significant differences from those of the Upper Continental Crust (UCC; Condie, 1993) can be observed, with the exception of $\mathrm{CaO}$ (avg. $0.8 \mathrm{wt}$

\%; UCC: 3.36 wt\%). Low values for $\mathrm{SiO}_{2} / \mathrm{Al}_{2} \mathrm{O} 3, \mathrm{~K} 2 \mathrm{O} / \mathrm{Na} 2 \mathrm{O}, \mathrm{Al} 2 \mathrm{O} 3 / \mathrm{Na} 2 \mathrm{O}$ y $\mathrm{Al} 2 \mathrm{O} 3 / \mathrm{Ti} 2 \mathrm{O}$ ratios (avg. 4.4, 0.8, 4.6 and 21.1, respectively), are similar to those of the Lower Alcudian greywackes (avg. 5.2, 0.7, 4.6 and 18.8, respectively; Fuenlabrada et al., 2016), and lay within the typical range for an upper continental crust provenance (4.5, 0.9, 4.5 and 24.2, respectively; Condie, 1993). Such ratios are consistent with an immature character for these metasedimentary rocks. The PIA values 
Table 1

Whole rock major and trace element data of Serie Negra greywackes (Late Ediacaran).

\begin{tabular}{|c|c|c|c|c|c|c|c|c|c|c|c|c|c|c|c|c|}
\hline Sample & OV-1 & OV-2 & ov-3 & OV-6 & OV-7 & OV-8 & OV-9 & OV-10 & OV-11 & OV-12 & oV-13 & OV-14 & OV-15 & OV-16 & OV-17 & OV-18 \\
\hline $\mathrm{SiO}_{2}$ & 60,09 & 67,34 & 60,09 & 70,21 & 69,88 & 63,39 & 60,34 & 61,63 & 67,88 & 69,41 & 63,37 & 67,39 & 70,56 & 64,35 & 69,41 & 70,42 \\
\hline $\mathrm{TiO}_{2}$ & 0,933 & 0,746 & 0,951 & 0,636 & 0,687 & 0,834 & 0,94 & 0,865 & 0,682 & 0,611 & 0,699 & 0,625 & 0,633 & 0,753 & 0,575 & 0,638 \\
\hline $\mathrm{Al2O}_{3}$ & 17,47 & 14,61 & 17,08 & 13,83 & 13,44 & 16,6 & 16,7 & 16,96 & 14,11 & 13,71 & 16,58 & 15,47 & 13,92 & 16,17 & 14,38 & 14,49 \\
\hline $\mathrm{Fe}_{2} \mathbf{O}_{3(\mathrm{~T})}$ & 7,9 & 5,35 & 8,01 & 4,39 & 4,39 & 6,52 & 8,01 & 7,41 & 4,81 & 4,54 & 5,6 & 4,95 & 4,5 & 6,23 & 4,07 & 4,29 \\
\hline Mno & 0,093 & 0,059 & 0,076 & 0,045 & 0,036 & 0,072 & 0,091 & 0,092 & 0,054 & 0,053 & 0,051 & 0,053 & 0,046 & 0,047 & 0,05 & 0,049 \\
\hline MgO & 3,23 & 2,24 & 3,4 & 2,29 & 2,56 & 3,36 & 4,07 & 3,65 & 2,78 & 2,58 & 2,28 & 1,94 & 1,58 & 2,39 & 1,51 & 1,53 \\
\hline $\mathrm{CaO}$ & 0,88 & 0,86 & 0,94 & 0,59 & 0,63 & 0,58 & 0,7 & 0,57 & 0,56 & 0,57 & 0,69 & 0,85 & 0,71 & 0,66 & 1,37 & 1 \\
\hline $\mathrm{Na}_{2} \mathrm{O}$ & 2,09 & 3,3 & 2,27 & 5,29 & 5,38 & 4,27 & 3,09 & 3,34 & 5,25 & 5,15 & 3,26 & 3,7 & 3,62 & 2,19 & 3,55 & 3,7 \\
\hline $\mathbf{K}_{2} \mathbf{O}$ & 4,23 & 2,22 & 3,53 & 0,44 & 0,27 & 1,48 & 2,13 & 2,01 & 0,54 & 0,56 & 3,79 & 3,29 & 2,65 & 3,62 & 2,79 & 2,56 \\
\hline $\mathbf{P}_{2} \mathbf{O}_{5}$ & 0,25 & 0,18 & 0,35 & 0,16 & 0,17 & 0,23 & 0,29 & 0,21 & 0,17 & 0,18 & 0,18 & 0,17 & 0,14 & 0,19 & 0,15 & 0,17 \\
\hline LOI & 3,4 & 2,18 & 3,31 & 1,76 & 1,8 & 2,84 & 4,04 & 3,35 & 2,1 & 2,11 & 2,76 & 2,28 & 2,08 & 3,91 & 1,53 & 1,83 \\
\hline PIA & 74,4 & 65 & 74,2 & 58,7 & 57,8 & 66,6 & 71,8 & 71 & 59,4 & 59,1 & 66,9 & 62,2 & 61,5 & 73,8 & 58,8 & 61 \\
\hline Total & 100,6 & 99,09 & 99,99 & 99,63 & 99,24 & 100,2 & 100,4 & 100,1 & 98,94 & 99,48 & 99,25 & 100,7 & 100,4 & 100,5 & 99,39 & 100,7 \\
\hline $\mathrm{SiO}_{2} / \mathrm{Al}_{2} \mathrm{O}_{3}$ & 3,44 & 4,61 & 3,52 & 5,08 & 5,2 & 3,82 & 3,61 & 3,63 & 4,81 & 5,06 & 3,82 & 4,36 & 5,07 & 3,98 & 4,83 & 4,86 \\
\hline $\mathrm{K}_{2} \mathrm{O} / \mathrm{Na}_{2} \mathrm{O}$ & 2,02 & 0,67 & 1,56 & 0,08 & 0,05 & 0,35 & 0,69 & 0,6 & 0,1 & 0,11 & 1,16 & 0,89 & 0,73 & 1,65 & 0,79 & 0,69 \\
\hline $\mathrm{Al}_{2} \mathrm{O}_{3} / \mathrm{Na}_{2} \mathrm{O}$ & 8,36 & 4,43 & 7,52 & 2,61 & 2,5 & 3,89 & 5,4 & 5,08 & 2,69 & 2,66 & 5,09 & 4,18 & 3,85 & 7,38 & 4,05 & 3,92 \\
\hline $\mathrm{Al}_{2} \mathrm{O}_{3} / \mathrm{TiO}_{2}$ & 18,72 & 19,58 & 17,96 & 21,75 & 19,56 & 19,9 & 17,77 & 19,61 & 20,69 & 22,44 & 23,72 & 24,75 & 21,99 & 21,47 & 25,01 & 22,71 \\
\hline Ва & 1101 & 716 & 765 & 211 & 88 & 411 & 680 & 489 & 175 & 258 & 725 & 755 & 846 & 742 & 793 & 660 \\
\hline $\mathbf{R b}$ & 126 & 72 & 114 & 10 & 6 & 35 & 51 & 51 & 13 & 11 & 144 & 130 & 98 & 135 & 100 & 96 \\
\hline $\mathbf{S r}$ & 135 & 193 & 148 & 171 & 136 & 115 & 97 & 105 & 148 & 130 & 109 & 164 & 155 & 84 & 211 & 182 \\
\hline Cs & 2,4 & 1,6 & 2,4 & 0,1 & 0,1 & 0,5 & 0,7 & 0,6 & 0,2 & 0,2 & 11,2 & 8 & 6,3 & 9,1 & 7,5 & 9,4 \\
\hline Ta & 1 & 0,7 & 0,84 & 0,76 & 0,81 & 0,88 & 0,92 & 0,86 & 0,83 & 0,75 & 0,92 & 0,97 & 0,86 & 0,94 & 0,81 & 0,87 \\
\hline Nb & 12,3 & 7,8 & 11,6 & 7,8 & 8,8 & 11,8 & 12,7 & 11,3 & 9,7 & 7,7 & 10,3 & 10,8 & 9,3 & 11,4 & 8,8 & 10 \\
\hline Hf & 4 & 5,1 & 4 & 8,7 & 10,3 & 4,6 & 4,2 & 4,5 & 10,4 & 6,7 & 3,9 & 5 & 8,6 & 4,2 & 5,6 & 7,9 \\
\hline $\mathrm{Zr}$ & 158 & 207 & 164 & 382 & 459 & 181 & 163 & 172 & 442 & 294 & 155 & 200 & 373 & 159 & 225 & 335 \\
\hline $\mathbf{Y}$ & 27,1 & 23,4 & 34,7 & 21,7 & 20,2 & 27,3 & 25,5 & 25,8 & 24,5 & 20,2 & 25,8 & 23,7 & 24,4 & 18,9 & 21,7 & 25 \\
\hline $\mathbf{P b}$ & 37 & 25 & 22 & 10 & 6 & 9 & 9 & 15 & $<5$ & 6 & 8 & 10 & 14 & 15 & 22 & 17 \\
\hline Th & 8,48 & 6,59 & 8,14 & 8,96 & 9,88 & 8,73 & 8,94 & 8,67 & 9,95 & 8,14 & 10,3 & 11,1 & 11,1 & 10,3 & 8,89 & 9,29 \\
\hline $\mathbf{U}$ & 1,88 & 1,64 & 2,47 & 1,69 & 1,88 & 2,42 & 2,44 & 2,22 & 1,72 & 1,55 & 2,71 & 2,78 & 3,68 & 4,37 & 3,22 & 4,36 \\
\hline $\mathrm{Cr}$ & 110 & 100 & 110 & 90 & 100 & 100 & 110 & 110 & 100 & 80 & 80 & 70 & 60 & 90 & 60 & 70 \\
\hline $\mathrm{Ni}$ & 70 & 40 & 60 & 30 & 30 & 50 & 60 & 60 & 30 & 30 & 40 & 30 & 30 & 40 & 20 & 20 \\
\hline Co & 18 & 24 & 16 & 16 & 17 & 18 & 21 & 20 & 17 & 14 & 12 & 17 & 15 & 10 & 19 & 17 \\
\hline $\mathbf{v}$ & 171 & 108 & 172 & 79 & 86 & 126 & 157 & 139 & 88 & 83 & 107 & 84 & 77 & 111 & 71 & 74 \\
\hline Sc & 20 & 13 & 20 & 10 & 11 & 16 & 20 & 18 & 12 & 11 & 14 & 11 & 10 & 15 & 10 & 10 \\
\hline $\mathrm{Cu}$ & 60 & 10 & 50 & 10 & $<10$ & 10 & 40 & 40 & $<10$ & 10 & 30 & 20 & 20 & 40 & 10 & 20 \\
\hline Zn & 160 & 180 & 90 & 40 & $<30$ & 50 & 60 & 90 & 30 & 30 & 80 & 80 & 60 & 90 & 60 & 50 \\
\hline Ga & 24 & 17 & 23 & 15 & 16 & 21 & 25 & 23 & 17 & 16 & 22 & 20 & 17 & 21 & 17 & 17 \\
\hline $\mathbf{T i}$ & 5593 & 4472 & 5701 & 3813 & 4119 & 5000 & 5635 & 5186 & 4089 & 3663 & 4191 & 3747 & 3795 & 4514 & 3447 & 3825 \\
\hline La & 39,5 & 34,7 & 38 & 42 & 41,8 & 42,3 & 34,4 & 37,4 & 46,7 & 39 & 34 & 27,7 & 28 & 12,1 & 34,8 & 37,3 \\
\hline $\mathrm{Ce}$ & 79,2 & 66,6 & 77,7 & 80,8 & 82 & 83,8 & 64 & 74,5 & 93,1 & 74,9 & 63,1 & 59,7 & 60 & 31 & 67,3 & 71,6 \\
\hline $\mathrm{Pr}$ & 9,12 & 7,58 & 9,27 & 9,04 & 9,14 & 9,59 & 8,01 & 8,59 & 10,2 & 8,55 & 7,73 & 6,58 & 6,17 & 3 & 7,81 & 8,17 \\
\hline Nd & 34,6 & 28,3 & 36,3 & 32,4 & 31,9 & 35,4 & 30,6 & 32,2 & 35,8 & 30,7 & 29,3 & 24 & 23,2 & 11,5 & 28,4 & 29,9 \\
\hline Sm & 7,02 & 5,35 & 7,42 & 6,12 & 5,78 & 6,93 & 6,05 & 6,33 & 6,26 & 5,8 & 5,79 & 4,85 & 4,76 & 2,65 & 5,52 & 5,82 \\
\hline Eu & 1,67 & 1,44 & 1,65 & 1,27 & 1,08 & 1,49 & 1,31 & 1,46 & 1,37 & 1,18 & 1,21 & 1,02 & 0,986 & 0,679 & 1,25 & 1,28 \\
\hline Gd & 6 & 4,65 & 6,84 & 4,74 & 4,37 & 5,89 & 5,18 & 5,42 & 5,08 & 4,41 & 5,03 & 4,08 & 4,16 & 2,65 & 4,72 & 4,86 \\
\hline $\mathbf{T b}$ & 0,92 & 0,69 & 1,02 & 0,71 & 0,67 & 0,88 & 0,84 & 0,84 & 0,78 & 0,66 & 0,79 & 0,67 & 0,67 & 0,51 & 0,72 & 0,78 \\
\hline Dy & 5,14 & 4,14 & 6,15 & 3,91 & 3,84 & 5,01 & 4,82 & 4,8 & 4,47 & 3,88 & 4,52 & 4,05 & 4,27 & 3,17 & 3,97 & 4,39 \\
\hline Ho & 1 & 0,8 & 1,16 & 0,76 & 0,73 & 0,98 & 0,94 & 0,92 & 0,87 & 0,73 & 0,87 & 0,8 & 0,85 & 0,66 & 0,76 & 0,86 \\
\hline Er & 2,83 & 2,29 & 3,37 & 2,26 & 2,12 & 2,72 & 2,67 & 2,66 & 2,6 & 2,15 & 2,56 & 2,38 & 2,46 & 2,05 & 2,24 & 2,54 \\
\hline $\mathrm{Tm}$ & 0,414 & 0,325 & 0,498 & 0,34 & 0,324 & 0,389 & 0,406 & 0,381 & 0,388 & 0,32 & 0,379 & 0,357 & 0,376 & 0,344 & 0,328 & 0,384 \\
\hline $\mathbf{Y b}$ & 2,79 & 2,25 & 3,07 & 2,31 & 2,28 & 2,67 & 2,72 & 2,62 & 2,5 & 2,23 & 2,58 & 2,51 & 2,59 & 2,29 & 2,17 & 2,53 \\
\hline Lu & 0,433 & 0,37 & 0,454 & 0,365 & 0,366 & 0,41 & 0,412 & 0,426 & 0,412 & 0,347 & 0,394 & 0,393 & 0,406 & 0,367 & 0,35 & 0,381 \\
\hline$\Sigma$ REE & 190,64 & 159,49 & 192,90 & 187,03 & 186,40 & 198,46 & 162,36 & 178,55 & 210,53 & 174,86 & 158,25 & 139,09 & 138,90 & 72,97 & 160,34 & 170,80 \\
\hline $\mathbf{E u} / \mathbf{E u} *$ & 0,79 & 0,89 & 0,71 & 0,72 & 0,66 & 0,72 & 0,72 & 0,77 & 0,75 & 0,72 & 0,69 & 0,70 & 0,68 & 0,79 & 0,75 & 0,74 \\
\hline$(\mathbf{G d} / \mathbf{Y b})_{N}$ & 1,71 & 1,65 & 1,78 & 1,64 & 1,53 & 1,76 & 1,52 & 1,65 & 1,62 & 1,58 & 1,55 & 1,30 & 1,28 & 0,92 & 1,73 & 1,53 \\
\hline$(\mathrm{La} / \mathrm{Yb})_{\mathrm{N}}$ & 9,47 & 10,31 & 8,28 & 12,16 & 12,26 & 10,59 & 8,46 & 9,55 & 12,49 & 11,69 & 8,81 & 7,38 & 7,23 & 3,53 & 10,72 & 9,86 \\
\hline La/Th & 4,66 & 5,27 & 4,67 & 4,69 & 4,23 & 4,85 & 3,85 & 4,31 & 4,69 & 4,79 & 3,30 & 2,50 & 2,52 & 1,17 & 3,91 & 4,02 \\
\hline $\mathrm{La} / \mathrm{Sc}$ & 1,98 & 2,67 & 1,90 & 4,20 & 3,80 & 2,64 & 1,72 & 2,08 & 3,89 & 3,55 & 2,43 & 2,52 & 2,80 & 0,81 & 3,48 & 3,73 \\
\hline Th/Sc & 0,42 & 0,51 & 0,41 & 0,90 & 0,90 & 0,55 & 0,45 & 0,48 & 0,83 & 0,74 & 0,74 & 1,01 & 1,11 & 0,69 & 0,89 & 0,93 \\
\hline $\mathrm{Ti} / \mathrm{Zr}$ & 35,40 & 21,60 & 34,76 & 9,98 & 8,97 & 27,62 & 34,57 & 30,14 & 9,25 & 12,45 & 27,03 & 18,73 & 10,17 & 28,39 & 15,32 & 11,41 \\
\hline
\end{tabular}

Oxides are in weight percent (wt \%).Trace elements are in parts per million (ppm). LOl: loss on ignition. 
(Plagioclase Index of Alteration; Fedo et al., 1995), ranging from 58 to 74 (avg. 65; Table 1), are lower than those of PAAS (79), and suggest limited alteration in the source area, thus indicating restricted effect of sedimentary transport over plagioclase and K-feldspar.

The pattern of REE in the siliciclastic rocks from the Obejo- Valsequillo Domain is similar to that of the Lower Alcudian metagreywackes (Fig. 5A), except for sample OV-16, which displays deple- tion in LREE. The chondrite-normalized patterns (Nakamura, 1974) are similar to those of PAAS, being characterized by enrichment in LREErelative to HREE (avg. LaN/YbN: 9.5), which display nearly flat patterns (avg.GdN/YbN: 1.5). All the samples show negative Eu anomaly, whose values range between 0.66 and 0.89 (avg. 0.74). These features, as in the case of the Lower Alcudian series, indicate igneous provenance from an upper continental crustal source (Cullers, 1994). They are similar to the average UCC pattern included in Fig. 5A, and could also be ex- plained by a certain degree of homogenization through sedimentary processes (McLennan et al., 1990; Taylor and McLennan, 1981).

$\mathrm{La} / \mathrm{Th}$ and Th/Sc values for the Obejo-Valsequillo metagreywackes 


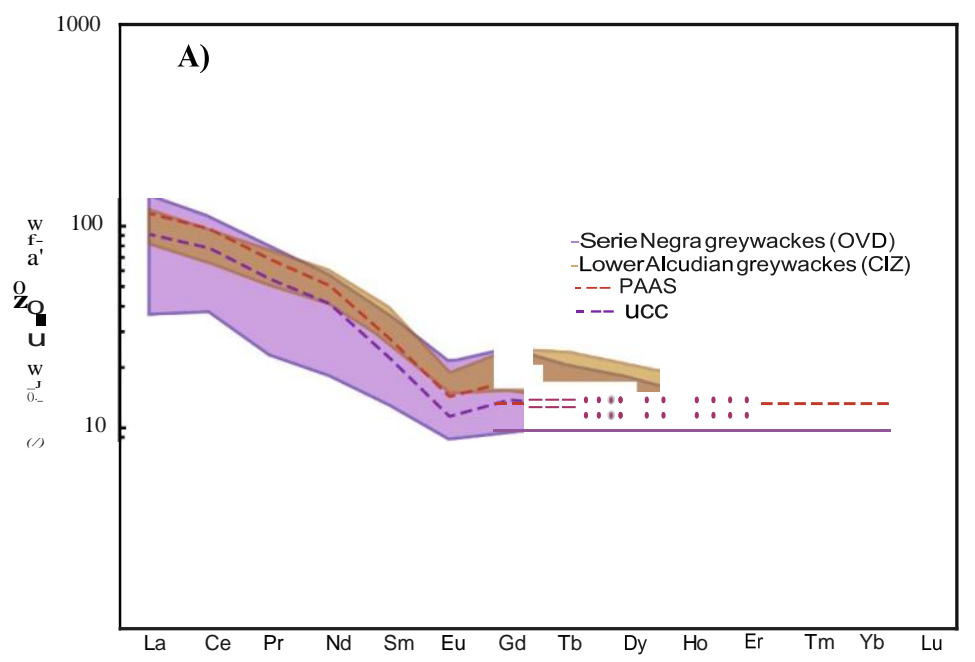

10.00

B)

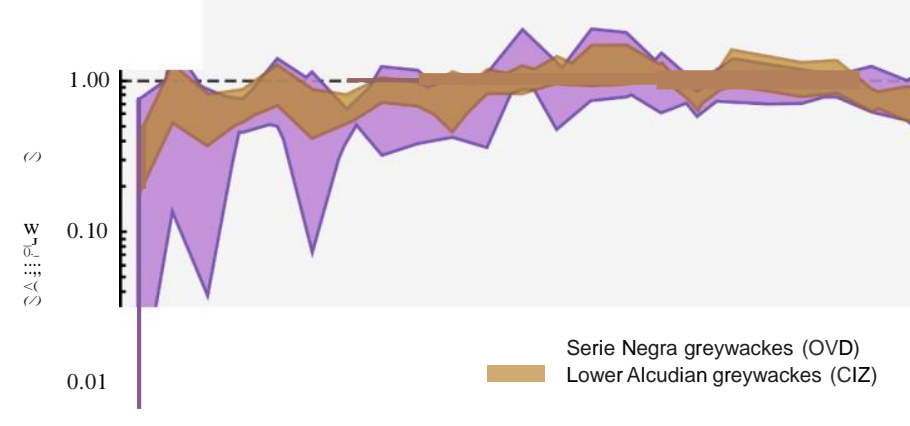

0.00 Cs Ba Rb Th U K Nb La Ce Sr Nd P Sm Zr HI Eu Ti Dy Y Er Yb Sc Cr Ni

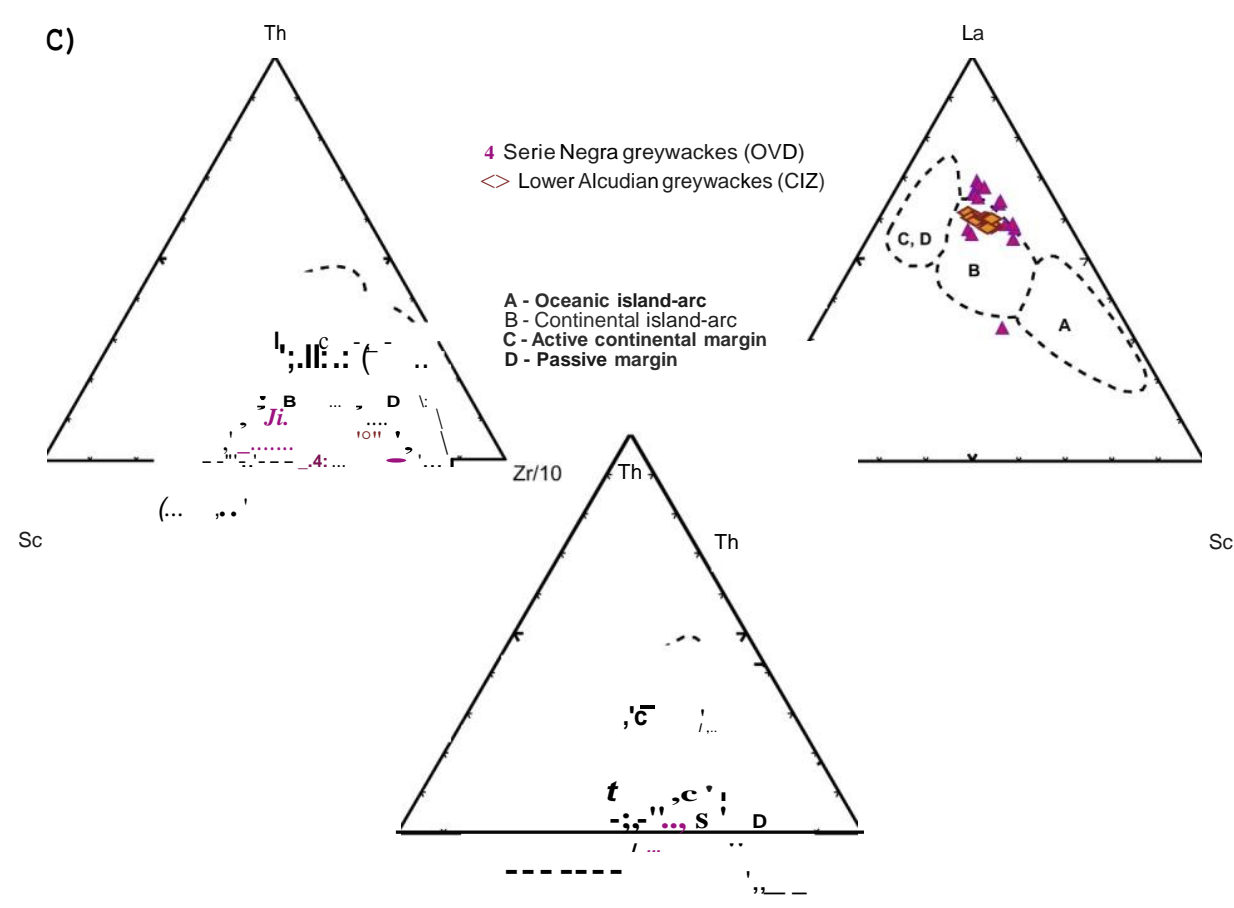




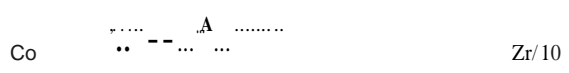

Fig. 5. Chemical diagrams for Ediacaran metagreywackes from the Serie Negra and Lower Alcudian (Fuenlabrada et al., 2016). A) Chondrite normalized REE plot (Nakamura, 1974); dotted lines correspond to the PAAS (Post Archean Australian Shale; Taylor and McLennan, 1985) and UCC (Upper Continental Crust; Condie, 1993). B) PAAS normalized trace elements diagram. C) Trace elements diagrams with tectonic setting discrimination fields (after Bhatia and Crook, 1986). 
Table 2

Whole rock Nd isotope data of Obejo-Valsequillo (Serie Negra) and Lower Alcudian greywackes (Late Ediacaran).

\begin{tabular}{|c|c|c|c|c|c|c|c|c|c|}
\hline Sample & Sm & Nd & $147 \mathrm{Sm} / 144 \mathrm{Nd}$ & $\mathrm{f}_{\mathrm{sm} / \mathrm{Nd}}$ & ${ }^{143} \mathrm{Nd} /{ }^{144} \mathrm{Nd}$ & \pm StErr* $10^{-6}$ & $\varepsilon N d_{(0)}$ & $\varepsilon \mathrm{Nd}_{(\mathrm{T})}{ }^{a}$ & $\operatorname{TDM}(\mathrm{Ma})^{\mathrm{b}}$ \\
\hline OV-1 & 5,24 & 26,25 & 0,1206 & $-0,39$ & 0,512008 & 1 & $-12,3$ & $-6,8$ & 1692 \\
\hline OV-2 & 4,08 & 21,40 & 0,1151 & $-0,41$ & 0,511955 & 1 & $-13,3$ & $-7,4$ & 1679 \\
\hline OV-3 & 5,80 & 28,22 & 0,1242 & $-0,37$ & 0,512037 & 1 & $-11,7$ & $-6,5$ & 1711 \\
\hline OV-6 & 4,61 & 25,26 & 0,1103 & $-0,44$ & 0,512050 & 2 & $-11,5$ & $-5,2$ & 1463 \\
\hline OV-7 & 4,29 & 24,23 & 0,1069 & $-0,46$ & 0,511776 & 1 & $-16,8$ & $-10,3$ & 1807 \\
\hline OV-8 & 5,33 & 27,62 & 0,1167 & $-0,41$ & 0,512137 & 1 & $-9,8$ & $-4,0$ & 1421 \\
\hline OV-9 & 4,56 & 22,87 & 0,1204 & $-0,39$ & 0,511953 & 2 & $-13,4$ & $-7,9$ & 1778 \\
\hline OV-10 & 4,54 & 23,11 & 0,1187 & $-0,40$ & 0,511956 & 1 & $-13,3$ & $-7,7$ & 1741 \\
\hline OV-11 & 4,49 & 25,86 & 0,1049 & $-0,47$ & 0,511588 & 1 & $-20,5$ & $-13,9$ & 2040 \\
\hline OV-12 & 4,27 & 23,35 & 0,1105 & $-0,44$ & 0,511906 & 2 & $-14,3$ & $-8,1$ & 1678 \\
\hline OV-13 & 4,25 & 21,27 & 0,1209 & $-0,39$ & 0,512065 & 2 & $-11,2$ & $-5,7$ & 1603 \\
\hline OV-14 & 3,56 & 17,76 & 0,1213 & $-0,38$ & 0,512032 & 1 & $-11,8$ & $-6,4$ & 1664 \\
\hline OV-15 & 3,25 & 16,28 & 0,1205 & $-0,39$ & 0,511877 & 1 & $-14,8$ & $-9,4$ & 1907 \\
\hline OV-16 & 2,34 & 10,24 & 0,1382 & $-0,30$ & 0,512049 & 2 & $-11,5$ & $-7,3$ & 2006 \\
\hline OV-17 & 4,52 & 23,62 & 0,1157 & $-0,41$ & 0,512038 & 1 & $-11,7$ & $-5,9$ & 1560 \\
\hline OV-18 & 4,10 & 21,68 & 0,1142 & $-0,42$ & 0,511959 & 1 & $-13,2$ & $-7,3$ & 1659 \\
\hline CIA-13 & 3,38 & 16,74 & 0,1220 & $-0,38$ & 0,512280 & 2 & $-7,0$ & $-1,6$ & 1269 \\
\hline CIA-14 & 3,78 & 18,81 & 0,1214 & $-0,38$ & 0,512269 & 2 & $-7,2$ & $-1,8$ & 1278 \\
\hline CIA-15 & 3,28 & 16,10 & 0,1230 & $-0,37$ & 0,512291 & 2 & $-6,8$ & $-1,4$ & 1263 \\
\hline CIA-16 & 3,18 & 15,57 & 0,1236 & $-0,37$ & 0,512293 & 2 & $-6,7$ & $-1,5$ & 1268 \\
\hline CIA-17 & 3,68 & 18,18 & 0,1223 & $-0,38$ & 0,512290 & 2 & $-6,8$ & $-1,4$ & 1256 \\
\hline CIA-18 & 3,24 & 15,79 & 0,1242 & $-0,37$ & 0,512293 & 1 & $-6,7$ & $-1,5$ & 1277 \\
\hline CIA-19 & 3,49 & 17,07 & 0,1236 & $-0,37$ & 0,512277 & 2 & $-7,0$ & $-1,8$ & 1295 \\
\hline CIA-20 & 3,40 & 16,77 & 0,1224 & $-0,38$ & 0,512266 & 1 & $-7,2$ & $-1,9$ & 1296 \\
\hline CIA-21 & 6,33 & 29,50 & 0,1298 & $-0,34$ & 0,512310 & 2 & $-6,4$ & $-1,6$ & 1329 \\
\hline CIA-22 & 6,69 & 31,95 & 0,1265 & $-0,36$ & 0,512305 & 2 & $-6,5$ & $-1,4$ & 1290 \\
\hline CIA-23 & 5,33 & 26,38 & 0,1221 & $-0,38$ & 0,512258 & 2 & $-7,4$ & $-2,0$ & 1305 \\
\hline CIA-24 & 4,86 & 25,32 & 0,1161 & $-0,41$ & 0,512188 & 2 & $-8,8$ & $-3,0$ & 1334 \\
\hline
\end{tabular}

OV - Ediacaran Serie Negra greywackes (Obejo-Valsequillo Domain).

CIA - Ediacaran Lower Alcudian greywackes (Central Iberian Zone; Fuenlabrada et al., 2016).

${ }^{\mathrm{a}} \mathrm{eNd}(\mathrm{T})$ calculated for $565 \mathrm{Ma}$.

${ }^{b} \mathrm{Nd}$ model ages after DePaolo (1981).

Decay constant for ${ }^{147} \mathrm{Sm}: 6.54 \times 10^{-12} \mathrm{y}^{1}$ (Lugmair and Marti, 1978).

Present-day CHUR parameters: ${ }^{147} \mathrm{Sm} /{ }^{144} \mathrm{Nd}=0.1967 ;{ }^{143} \mathrm{Nd} /{ }^{144} \mathrm{Nd}=0.512638$ (Jacobsen and Wasserburg, 1980).

(avg. 3.96 and 0.72, respectively; Table 1) match those of the Lower Alcudian metasedimentary rocks (avg. 3.34 and 0.79; Fuenlabrada et al. 2016). Those ratios are slightly higher when compared to those of PAAS (2.6 and 0.9 , respectively), and to the UCC (2.7 and 0.7, respectively; Condie, 1993), what favours an intermediate-felsic provenance (Cullers, 2002). This interpretation is in agreement with the lower content in Sc, Cr, and Ni observed in both metasedimentary series.

Fig. 5B presents multivariation diagrams (following Thompson, 1982), normalized to PAAS, for both metasedimentary series. Resulting patterns show depletion in most LILE elements (Cs, Rb, and K), and larger variabilibity in the case of the metagreywackes of the Obejo- Valsequillo Domain, likely indicative of limited recycling. LILE ele- ments display a positive slope up to HFSE elements ( $\mathrm{Zr}, \mathrm{Hf}, \mathrm{Sm}$, HREE and Sc), which show values close to those of the PAAS. Both features, together with a Ti negative anomaly, are consistent with an active margin setting for the deposition of the two metasedimentary series (Winchester and Max, 1989).

The immature character and limited weathering/recycling deduced for the samples, allow the use of tectonic setting discrimination dia- grams. Ternary diagrams (La-Th-Sc, Th-Co-Zr/10 and Th-Sc-Zr/10; Fig. 5C), proposed by Bhatia and Crook (1986), suggest a similar geo- dynamic environment during the sedimentation of both Ediacaran series. All the samples plot tightly within the field characteristic for a basin connected to a volcanic arc built over a thinned continental crust (field B; Fig. $5 \mathrm{C}$ ). The values of $\mathrm{La} / \mathrm{Th}, \mathrm{La} / \mathrm{Sc}, \mathrm{Th} / \mathrm{Sc}$ and $\mathrm{Ti} / \mathrm{Zr}$ for both metasedimentary series reinforce this interpretation (Table 1 and Fuenlabrada et al., 2016), since the ratios are close to the range defined by Bhatia and Crook (1986) (2.36, 1.82, 0.85 and 19.70, respectively) as typical for this tectonic setting in particular.

According to the major and trace element geochemical data and comparisons presented in this chapter, it can be concluded that the 
whole rock geochemical composition of the Lower Alcudian and Serie Negra siliciclastic series are similar. Both series were deposited in a similar geodynamic setting, i.e. in the vicinity of an active volcanic arc built on a thinned section of a continental margin, probably the African margin of Gondwana.

\section{Sm-Nd isotope geochemistry}

Major and trace element geochemistry alone are not enough to constrain the paleogeographic position of the basin or basins in which Ediacaran sedimentation took place, neither to estimate the contribu- tion of major cratonic sources to the infill of the basins. Sm-Nd sys- tematics, on the other hand, can supply significant information in relation to these questions.

\subsection{Methodology}

In the new 16 samples, isotopic analyses were performed on pow- dered rocks milled at Universidad Complutense de Madrid. Sm-Nd isotopic analyses were performed at the Geochronology and Isotope Geochemistry Service of Universidad Complutense de Madrid, using Isotope Dilution Thermal Ionization Mass Spectrometry (IDTIMS). Samples were spiked with a mixed ${ }^{149} \mathrm{Sm}-{ }^{150} \mathrm{Nd}$ tracer and analysed in an IsotopXPhoenix spectrometer (TIMS), using a single collection and a dynamic multicollection mode for $\mathrm{Sm}$ and $\mathrm{Nd}$, respectively. The ${ }^{143} \mathrm{Nd} /{ }^{144} \mathrm{Nd}$ ratios were corrected for ${ }^{142} \mathrm{Ce}$ and ${ }^{144} \mathrm{Sm}$ interferences and normalized to ${ }^{146} \mathrm{Nd} /{ }^{144} \mathrm{Nd}=07219$ value (O'Nions et al., 1979) in order to correct procedural and instrumental mass fractionation. Drifts from La Jolla reference value (Lugmair et al., 1983) were corrected by analyzing the standard along with the samples, yielding an average value of ${ }^{143} \mathrm{Nd} /{ }^{144} \mathrm{Nd}=0.511851$ for 6 replicates , with an internal 
precision of $\pm 0.00002(2 \sigma)$. Analytical errors on the ${ }^{147} \mathrm{Sm} /{ }^{144} \mathrm{Nd}$ and ${ }^{143} \mathrm{Nd} /{ }^{144} \mathrm{Nd}$ ratios were estimated to be $<0.1 \%$ and $0.006 \%$, respec- tively.

The new Sm-Nd isotopic data from the Serie Negra (Ossa Morena Complex) will be now compared with equivalent data from the Lower Alcudian Series (Central Iberian Zone) published by Fuenlabrada et al. (2016) The isotopic Sm$\mathrm{Nd}$ values of these 28 samples are included in Table 2. ${ }^{147} \mathrm{Sm} /{ }^{144} \mathrm{Nd}$ values range from 0.1049 to 0.1396 (Table $2)$, with an average value $(0.1175)$ close to those of the upper crust $(0.12)$ and always under 0.165 , which has been considered as an upper filter for TDM calculations (Stern, 2002).

The study of the $\mathrm{Nd}$ isotope composition of siliciclastic rocks has contributed to understanding crustal evolution (McLennan et al., 1990; McLennan and Hemming, 1992). Crustal models consider that the Nd model ages for siliciclastic rocks, typically older than their maximum depositional ages, are an average for the moment of melt extraction for each individual component from its source (McCulloch and Wasserburg, 1978; Allegre and Rousseau, 1984; and others). Those ages represent a complex mixture of crustal terrigenous components re- sulting from preexisting sedimentary rocks, variably aged upper-crustal igneous rocks, and other juvenile components (McLennan and Hemming, 1992).

\subsection{Results}

Although the precise age of azoic sedimentary series may be con- troversial, the most probable depositional age for both Ediacaran series here compared is quite similar, as constrained by the age of underlying and overlying series and the maximum depositional age deduced from detrital zircons they contain. The reference ages for the calculation of the $\varepsilon N d$ (i) values have been set to $565 \mathrm{Ma}$ for both Ediacaran series. The Serie Negra samples show a range of highly negative values, with $\varepsilon N d(0)$ varying between -9.8 and -20.5 , and $\varepsilon N d(565)$ values between -4.0 and -13.9 , with an old TDM age that ranges from Mesoproterozoic to Paleoproterozoic (1421-2040 Ma) (Table 2). The siliciclastic rocks from the Lower Alcudian exhibit quite different values of $\varepsilon \mathrm{Nd}(0)$ (from

-6.4 to -8.8 ) and $\varepsilon \mathrm{Nd}(565)$ (from -1.4 to -3.0 ), as well as younger

$\mathrm{Nd}$ model ages (1256-1334 Ma) (Table 2). None of the ranges for the aforementioned values in the Central Iberian Zone even overlaps a little with any of those for the Ossa-Morena Complex.

Fig. 6 shows an $\varepsilon N d$ vs age $(\mathrm{Ga})$ diagram for both groups of Edia- caran siliciclastic rocks. Besides indicating the variation limits of their TDM values, that figure also includes a collection of $\mathrm{Nd}$ model ages from different regions (Linnemann and Romer, 2002) that are con- sidered relevant to discussing paleogeographic affinity between the Ediacaran series of the African paleo-margin of Gondwana. The dia-gram includes old isotopic signatures from the West African Craton and from the Amazonian Craton, along with other Nd model ages from more juvenile terranes. Intermediate ages, more common in other terranes, could reflect isotopic mixing between both sources. The provenance and isotopic sources of the Serie Negra (Obejo-Valsequillo Domain) and Lower Alcudian siliciclastic rocks (Central Iberian Zone) are a mixture between the West African Craton and other western terranes, such as West Avalonia in Atlantic Canada and Carolina. The Sm-Nd isotopic compositions of studied series suggest a provenance from areas domi- nated by pre-Mesoproterozoic cratonic crust, therefore lacking of Me-soproterozoic igneous activity. A provenance from the African paleo- margin of Gondwana is in good agreement with this set of observations. The same isotopic features are also a tool for tectonic discrimination, when considering the Sm/Nd fractionation from CHUR for crustal rocks (fSm/Nd; DePaolo, 1988). Fig. 7 shows a $\mathrm{fSm} / \mathrm{Nd}$ vs $\varepsilon \mathrm{Nd}(\mathrm{T})$ diagram that discriminates between passive and active margin settings (McLennan and Hemming, 1992). Siliciclastic rocks deposited in pas- sive margins or derived from cratonic areas tend to plot towards more negative $\varepsilon N d(T)$ values compared to those derived from source areas connected to active volcanic arcs, where the input of juvenile material 
is usually larger (McLennan and Hemming, 1992). Most of the studied samples plot in the overlapping region between active and passive margin, although the Ediacaran series here compared show different isotopic features. The samples of the Serie Negra yielded $\mathrm{fSm} / \mathrm{Nd}$ values ranging between -0.30 and -0.47 , while the Lower Alcudian samples are clearly distinguishable, since these plot within a more restricted range (fSm/ $\mathrm{Nd}$, from -0.34 to -0.41 ) (Fig. 7). The Serie Negra samples show larger affinity with cratonic regions, what alongside the volcanic arc setting for the deposition of both series, suggest that old cratonic sources were involved, being either part of the basement of the volcanic arc and/or from the neighboring continental region.

\section{Discussion}

In the SW of the Iberian Massif, the South-Portuguese Zone re- presents the southern margin of Laurussia, i.e. the Avalonian foreland collided with Gondwana during the assembly of Pangea in Devonian times (Figs. 1 and 2) (Díez Fernández et al., 2016). The Ossa-Morena Complex, in the Galicia - Ossa-Morena Zone (Arenas et al., 2016a), together with the other allochthonous complexes of the Iberian Massif (Díez Fernández and Arenas, 2015; Arenas et al., 2016b), define the most external margin of Gondwana, the region affected by the most intense dynamic in Variscan and pre-Variscan times. This interpretation is clearly confirmed at present by the existence in those complexes of a group of different ophiolitic units (Arenas and Sánchez Martínez, 2015; Arenas et al., 2018) and a pair of successive high-P metamorphic events dated at c. 400 and 370 Ma (Ordóñez Casado et al., 2001; Fernández- Suárez et al., 2007; Abati et al., 2010; Arenas et al., 2014; Díez Fernández et al., 2016). Several works have confirmed that the Ava- Ionian-African margin of Gondwana has been an active margin for a long time, at least between 750 and $500 \mathrm{Ma}$, the Avalonian-Cadomian arc (Rodríguez-Alonso et al., 2004; Pereira et al., 2006; Linnemann et al., 2008, 2014; von Raumer and Stampfli, 2008; Fuenlabrada et al., 2010; Albert et al., 2015a, 2015b, von Raumer et al., 2015; Andonaegui et al., 2016). According to this interpretation, the Central Iberian Zone very likely represents a back-arc basin located behind the most active part of the margin (Fernández-Suárez et al., 2014; Albert et al., 2015a; Orejana et al., 2015; Díez Fernández et al., 2016). The contrasting lo- cation of both Ediacaran series, Serie Negra and Lower Alcudian, de- posited respectively in the frontal arc and in the back-arc, explains the differences observed in the stratigraphic columns and in the intensity of the Ediacaran-Cambrian magmatism (Fig. 4). It has been even sug- gested that the Serie Negra was deposited in a fore-arc basin opened at

c. $600 \mathrm{Ma}$ during a short event of subduction roll-back accompanied by boninitic magmatism (Arenas et al., 2018).

The major and trace element geochemistry and the Sm-Nd isotopic data presented in this work are compatible with this peri-Gondwanan dynamic context. The siliciclastic rocks of the Serie Negra and Lower Alcudian have compositions suggesting a deposition in an active margin setting (Figs. 5 and 7). TDM values of the Serie Negra are significantly older (1421-2040 Ma) than those of the Lower Alcudian (1256-1334 Ma), which would situate its source areas in the periphery of a cratonic region (Figs. 6 and 7), very likely in the realm of the West African Craton. This interpretation is at odds with sedimentation of the studied section of the Serie Negra very close to the most active part of the Ediacaran magmatic arc, as old TDM values would require scarce supply of juvenile material coming from the arc. However, it can also point to the presence of a rather narrow active arc at that time, built on an external section of the margin of Gondwana detached from the West African Craton itself. This way, the basement of the magmatic arc would probably be Archean and/or Paleoproterozoic in age, as those are the ages for the oldest basement rocks found in the (submerged) lberian continental margin of the Cantabrian coast (Gardien et al., 2000) and in equivalent regions of the Channel Islands (Samson and D'Lemos, 1998).

$\mathrm{Nd}$ model ages (Fig. 6) indicate that the source areas for the Lower 


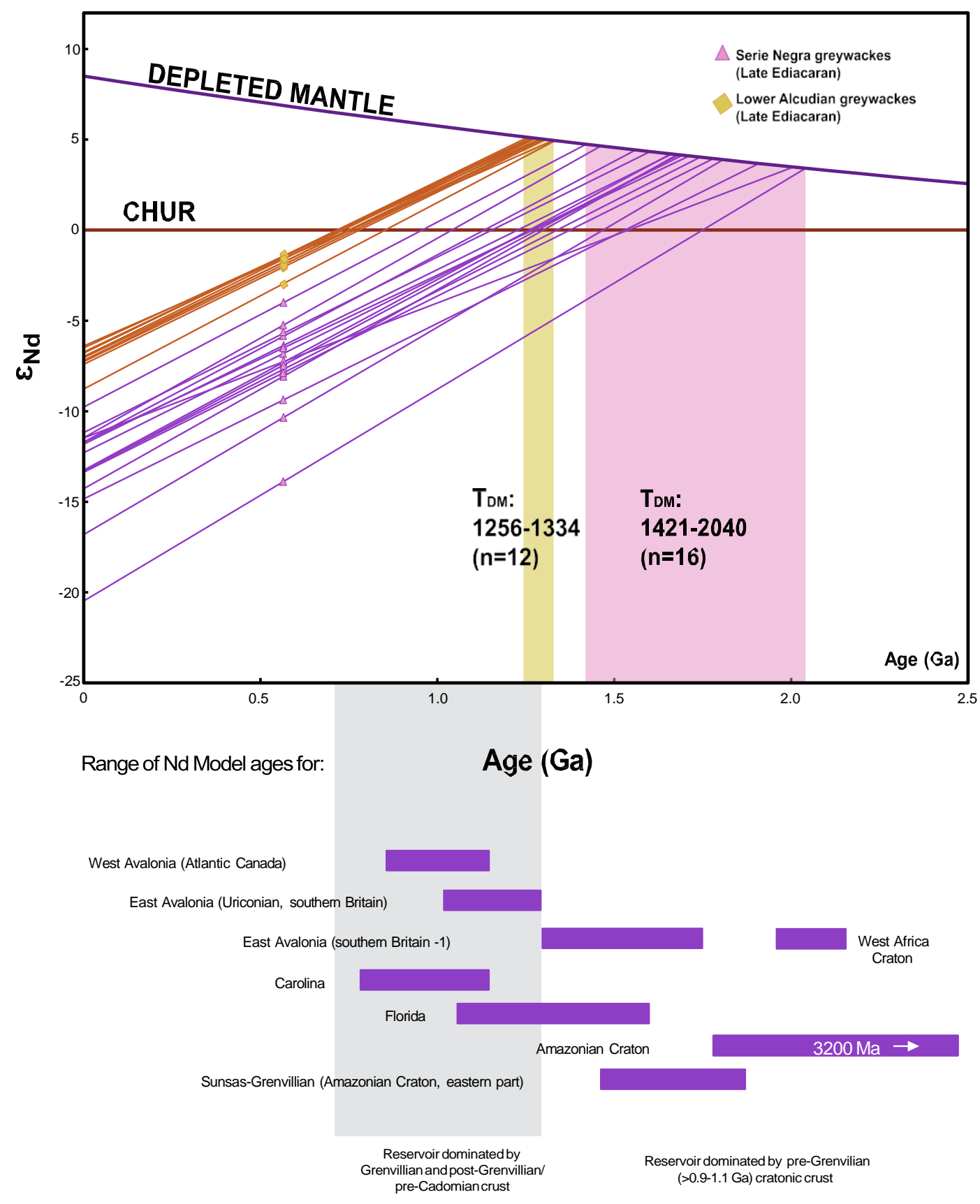

Fig. 6. $\varepsilon N d$ vs Age diagram showing TDM values of the Late Ediacaran siliciclastic rocks of the Lower Alcudian and Serie Negra series. The range of $\mathrm{Nd}$ model ages of selected regions are shown for comparison (Linnemann and Romer, 2002).

Alcudian (Central Iberian Zone) were isotopically younger than those for the Serie Negra (Ossa-Morena Complex), what at first would in- dicate deposition of the first at a greater distance from the West Africa Craton. The differences found in the Sm-Nd isotopic sources make it hard to sustain that the siliciclastic rocks of the Lower Alcudian and Serie Negra were deposited close to one another, as they are observed today. With the data at hand, the most probable scenario is that the deposition of the Lower Alcudian and Serie Negra took place at distant sections within the Gondwana margin, either in rather distant sections of the same sedimentary basin (e.g., two flanks of a back-arc basin), or even in two separate basins within the same arc-system.

Comparative provenance analysis based on U-Pb geochronology of detrital zircons favors a more eastern Ediacaran position of the Central Iberian Zone relative to the Ossa-Morena Complex along the peri- Gondwanan realm (Fig. 8; Díez Fernández et al., 2010; Fernández- 
Suárez et al., 2014; Albert et al., 2015a, Cambeses et al., 2017). This is yet another evidence on the tectonic transport needed to explain the current juxtaposition of the Ediacaran series of the Central Iberian Zone and OssaMorena Complex (Fig. 2). Such tectonic transport could have been achieved during any of the three main orogenic events recorded in the Iberian Massif after deposition of the Ediacaran series, namely: (i) latest Ediacaran convergence, (ii) Early Paleozoic rifting, or (iii) Var- iscan collision.

On a preliminary analysis, the current juxtaposition of the Central Iberian Zone and the Ossa-Morena Complex would require a component of dextral lateral movement along the margin of Gondwana over at least one major fault (Fig. 8). Although no lateral movements have been proved for the Early Paleozoic rifting stage, we cannot rule out the possibility that some lateral movement occurred at this time. Never- theless, the rifting stage would not explain alone the current terrane 


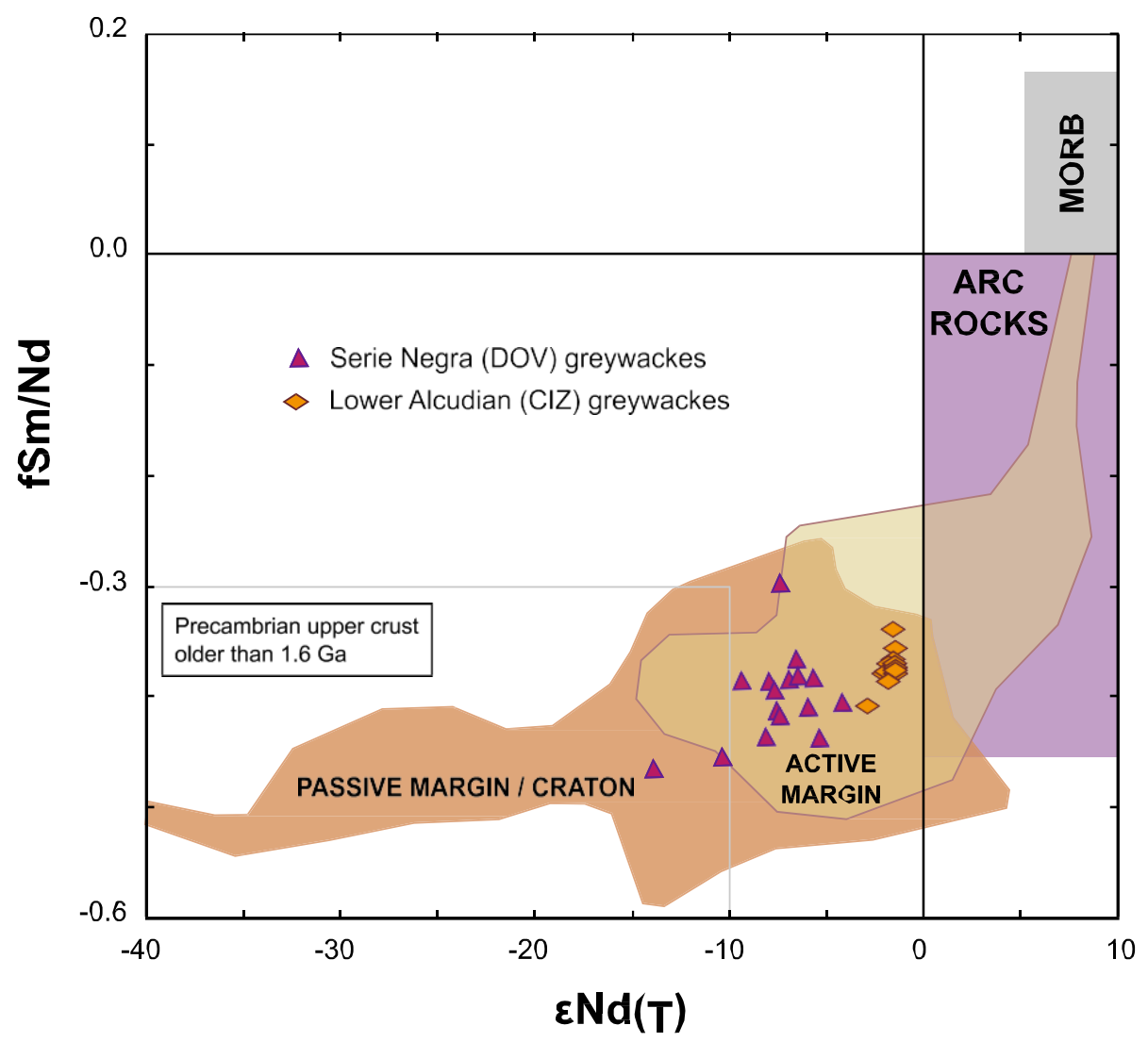

Fig. 7. $\mathrm{f}_{\mathrm{Sm} / \mathrm{Nd}}$ vs $\varepsilon \mathrm{Nd}_{(\mathrm{T})}$ diagram (McLennan and Hemming, 1992) showing the isotopic composition of the Late Ediacaran siliciclastic rocks.

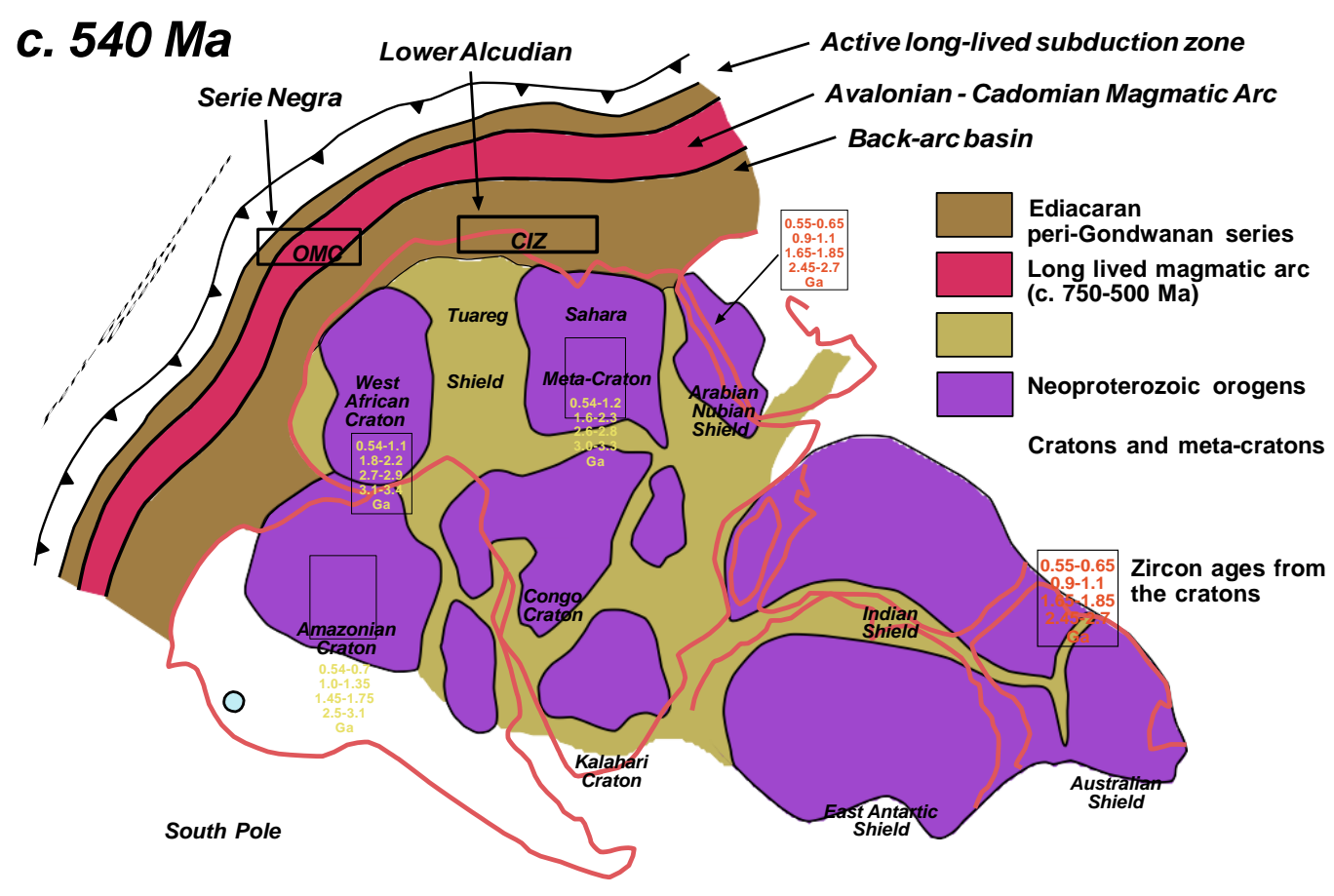

Fig. 8. Paleogeographic reconstruction of Gondwana at c. 540 Ma showing the location inferred for the deposition of the Late Ediacaran series of the southern Central Iberian Zone (Lower Alcudian) and Obejo Valsequillo Domain (Ossa-Morena Complex, Serie Negra) in the periphery of the African margin. Paleogeography of Gondwana based on von Raumer and Stampfli (2008), Díez Fernández et al. (2010), Fernández-Suarez et al. (2014), Albert et al. (2015a) and Arenas et al. (2018). Numbers in squares are zircon ages in Ga, from Avigad et al. (2012), Linnemann et al. (2014) and Morag et al. (2012). OMC: 
Ossa - Morena Complex; CIZ: Central Iberian Zone. 
juxtaposition, as rift-related magmatism that occurs near the boundary between the Central Iberian Zone and the Ossa-Morena Complex (Díez Fernández et al., 2015) actually implies separation of terranes. Latest Ediacaran convergence has been recently found as responsible for the juxtaposition of Ediacaran series within the OssaMorena Complex (Díez Fernández et al., 2019). However, lateral components of con- vergence inferred for that period are sinistral, what would move away the terranes under discussion. Finally, Variscan deformation in the Iberian Massif has been largely acknowledged as the result of the pro- gressive dextral collision between Laurussia, Gondwana and their peri- continental terranes (e.g., Martínez Catalán, 1990, 2011). Such oro- genic scenario includes the lateral dextral components required for the juxtaposition of the studied series, but so far, no major strike-slip shear zone has been observed along the boundary between the Central Iberian Zone and the Ossa-Morena Complex that could have taken the right-lateral displacements required.

The current boundary between the northern Ossa-Morena Complex and the southern Central Iberian Zone is a dipslip Variscan extensional fault (Martín Parra et al., 2006). A normal fault like this cannot explain the juxtaposition of formerly distant terranes that were located laterally along the margin of Gondwana. This is because that fault actually moves away the two terranes and includes negligible, if any, along- strike movement. Díez Fernández and Arenas (2015) recognized the primary Variscan contact between the Ossa-Morena Complex and the Central Iberian Zone as a major thrust equivalent to the one that em- placed the Allochthonous Complexes of NW Iberia onto the Central Iberian Zone (Fig. 2). In a dextral convergence setting such as the Variscan orogeny, a major thrust like this one can achieve the juxta- position of distant terranes as required for the study case. In fact, the large tectonic transport inferred for this primary thrust, if measured across the margin of Gondwana (several hundred kilometers; Díez Fernández et al., 2016), makes it more likely that the two Ediacaran series here compared did not belong to two laterally distant sections of the same basin, but to two sections of two different basins within a broad Ediacaran periGondwanan arc-system.

Similar offsets in the pre-Variscan paleogeographic position of peri- Gondwanan terranes that are now juxtaposed by Variscan faults can also be observed in other sections of the orogen. The first one that was documented by provenance analysis of metasedimentary sequences was that of the Devonian suture zone exposed in NW Iberia. There, al- lochthonous terranes derived from westernmost positions along the margin of Gondwana (FernándezSuárez et al., 2003), are currently juxtaposed onto others that were located more to the East (Díez Fernández et al., 2010). This offset in the paleogeography mimics what is observed along the boundary between the ObejoValsequillo Domain and the Central Iberian Zone, thus reinforcing the idea that the latter represents another occurrence of the suture zone observed in NW Iberia. This way, geochemical and provenance (e.g., Sm-Nd) analysis of sedimentary sequences emerges as a reference tool for recognizing major tectonic boundaries within orogenic systems, the paleogeo- graphic offsets inferred for currently juxtaposed Ediacaran series being a promising target to use it. So far, the results obtained for the Iberian Massif are solid, thus a similar approach could be likely implemented in other areas with similar geology along the Variscan Orogen to test the existence of major tectonic boundaries in the absence of clear structural and petrological indicators.

\section{Conclusions}

In the Iberian Massif, the Sm-Nd isotopic composition of coeval Ediacaran siliciclastic rocks, located at each side of the Central Iberian Zone - Ossa Morena Complex boundary, is very different. To the south of that boundary (Ossa Morena Complex), the Serie Negra shows older TDM values ranging 1421-2040 Ma, and was probably deposited in the frontal part of a volcanic arc built on an extended section of the margin of the West Africa Craton. Immediately to the north (Central Iberian 
Zone), the Lower Alcudian Series has younger TDM values, in the range of 1256-1334 Ma, and was likely deposited in a peri-Gondwanan back- arc basin located more to the east of the West African Craton. The differences in Sm-Nd isotopic composition indicate contrasted source areas, and do not support the deposition of both series close to one another, as opposed to how they are observed today. The Sm-Nd data suggest a different location along the margin of Gondwana for the de- position of each series during Ediacaran times. A more eastern paleo- geographic position is inferred for the Central Iberian Zone relative to the Ossa-Morena Complex, as also supported by provenance analysis based on $\mathrm{U}-\mathrm{Pb}$ geochronology of detrital zircons. The boundary be- tween the Central Iberian Zone and the Obejo-Valsequillo Domain (Ossa-Morena Complex) is not transitional, as the current juxtaposition of Ediacaran series at each side requires significant tectonic transport. Although some contribution of Ediacaran (Cadomian) and Early Paleozoic structures cannot be ruled out, Variscan thrusting developed in a dextral convergence setting is found as the main contributor to the current juxtaposition of Ediacaran series along this boundary. This conclusion can be very likely extrapolated to some other equivalent boundaries throughout the Variscan Orogen.

\section{Acknowledgements}

Constructive reviews of the manuscript by Jean-Paul Liégeois and Jürgen von Raumer are kindly acknowledged. Financial support has been provided by the Spanish project CGL2016-76438-P (Ministerio de Economía, Industria y Competitividad).

\section{Appendix A. Supplementary data}

Supplementary data to this article can be found online at https:// doi.org/10.1016/j.precamres.2019.01.021.

\section{References}

Abati, J., Gerdes, A., Fernández-Suárez, J., Arenas, R., Whitehouse, M.J., Díez Fernández, R., 2010. Magmatism and early-Variscan continental subduction in the northern Gondwana margin recorded in zircons from the basal units of Galicia, NW Spain.

Geol. Soc. Am. Bull. 122, 219-235.

Albert, R., Arenas, R., Gerdes, A., Sánchez Martínez, S., Fernández-Suárez, J., 2015a. Provenance of the Variscan Upper Allochthon (Cabo Ortegal Complex, NW Iberian Massif). Gondwana Res. 28, 1434-1448.

Albert, R., Arenas, R., Gerdes, A., Sánchez Martínez, S., Marko, L., 2015b. Provenance of the HP-HT subducted margin in the Variscan belt (Cabo Ortegal Complex, NW Iberian Massif). J. Metamorph. Geol. 33, 959-979.

Allegre, C.J., Rousseau, D., 1984. The growth of the continent through geological time studied by Nd isotope analysis of shales. Earth Planet. Sci. Lett. 67, 19-34.

Andonaegui, P., Arenas, R., Albert, R., Sánchez Martínez, S., Díez Fernández, R., Gerdes, A., 2016. The last stages of the Avalonian-Cadomian arc in NW Iberian Massif: iso- topic and igneous record for a long-lived peri-Gondwanan magmatic arc.

Tectonophysics $681,6-14$.

Apalategui, O., Pérez-Lorente, F., 1983. Nuevos datos en el borde meridional de la Zona Centroibérica. El dominio Obejo-Valsequillo-Puebla de la Reina. Studia Geologica Salmanticensia 18, 193-200.

Arenas, R., Díez Fernández, R., Sánchez Martínez, S., Gerdes, A., Fernández-Suárez, J., Albert, R., 2014. Two-stage collision: exploring the birth of Pangea in the Variscan terranes. Gondwana Res. 25, 756-763.

Arenas, R., Sánchez Martínez, S., 2015. Variscan ophiolites in NW Iberia: tracking lost Paleozoic oceans and the assembly of Pangea. Episodes 38, 315-333.

Arenas, R., Díez Fernández, R., Rubio Pascual, F.J., Sánchez Martínez, S., Martín Parra, L.M., Matas, J., González del Tánago, J., Jiménez-Díaz, A., Fuenlabrada, J.M., Andonaegui, P., GarcíaCasco, A., 2016a. The Galicia-Ossa-Morena Zone: proposal for a new zone of the Iberian Massif. Variscan implications. Tectonophysics 681, 135-143.

Arenas, R., Sánchez Martínez, S., Díez Fernández, R., Gerdes, A., Abati, J., Fernández- Suárez, J., Andonaegui, P., González Cuadra, P., López Carmona, A., Albert, R., Fuenlabrada, J.M., Rubio Pascual, F.J., 2016b. Allochthonous terranes involved in the Variscan suture of NW Iberia: a review of their origin and tectonothermal evo- lution. Earth Sci. Rev. 161, 140-178. 
Arenas, R., Fernández-Suárez, J., Montero, P., Díez Fernández, R., Andonaegui, P., Sánchez Martínez, S., Albert, R., Fuenlabrada, J.M., Matas, J., Martín Parra, L.M., Rubio Pascual, F.J., Jiménez-Díaz, A., Pereira, M.F., 2018. The Calzadilla Ophiolite (SW Iberia) and the Ediacaran forearc evolution of the African margin of Gondwana. Gondwana Res. 58, 71-86.

Avigad, D., Gerdes, A., Morag, N., Bechstäd, T., 2012. Coupled U-Pb-Hf of detrital zircons 
of Cambrian sandstones from Morocco and Sardinia: implications for provenance and Precambrian crustal evolution of North Africa. Gondwana Res. 21, 690-703.

Bandrés, A., 2001. Evolución geodinámica poliorogénica de los dominios septentrionales de la ZOM. Universidad del País Vasco, pp. 377 Tesis Doctoral.

Bea, F., Montero, P., Talavera, C., Abu Anbar, M., Scarrow, J.H., Molina, J.F., Moreno, J.A., 2010. The palaeogeographic position of Central Iberia un Gondwana during the Ordovician: evidence from zircon chronology and Nd isotopes. Terra Nova 22, 342-346.

Bhatia, M.R., 1983. Plate tectonics and geochemical composition of sandstones. J. Geol. 91, 611-627.

Bhatia, M.R., Crook, K.A.W., 1986. Trace elements characteristics of greywackes and tectonic setting discrimination of sedimentary basins. Contrib. Miner. Petrol. 92, 181-193.

Cambeses, A., Scarrow, J.H., Montero, P., Lázaro, C., Bea, F., 2017. Palaeogeography and crustal evolution of the Ossa-Morena Zona, southwest Iberia, and the North Gondwana margin during the Cambro-Ordovician: a review of isotopic evidence. Int. Geol. Rev. 59, 94-130.

Carrington da Costa, J., 1950. Noticia sobre una carta geológica de Bucaco de Nery Delgado. Comunicações dos Serviços Geológicos de Portugal 1-27.

Carvalhosa, A., 1965. Contribuição para o conhecimento geológico da região entre Portel e Ficalho (Alentejo). Memorias dos Serviços Geológicos de Portugal. Nova Série 11, 1-32.

Condie, K.C., 1993. Chemical composition and evolution of the upper continental crust: contrasting results from surface samples and shales. Chem. Geol. 104, 1-37.

Cullers, R.L., 1994. The controls on the major and trace element variation of shales, siltstones and sandstones of Pennsylvanian-Permian age from uplifted continental blocks in Colorado to platform sediment in Kansas, USA. Geochim. Cosmochim. Acta 58, 4955-4972.

Cullers, R.L., 2002. Implications of elemental concentrations for provenance, redox conditions, and metamorphic studies of shales and limestones near Pueblo, CO, USA. Chem. Geol. 191, 305-327.

DePaolo, D.J., 1981. A neodymiun and strontium isotopic study of the Mesozoic cal- calkaline granitic batholiths of the Sierra-Nevada and Peninsular ranges, California. J. Geophys. Res. 86, 470-488.

DePaolo, D.J., 1988. Neodymium Isotope Geochemistry. Springer-Verlag, Berlin, pp. 181. Díez

Fernández, R., Arenas, R., 2015. The Late Devonian Variscan suture of the Iberian Massif: a correlation of 96-100.

high-pressure belts in NW and SW Iberia. Tectonophysics 654,

Díez Fernández, R., Martínez Catalán, J.R., Gerdes, A., Abati, J., Arenas, R., y Fernández- Suárez, J., 2010. U-Pb ages of detrital zircons from the basal allochthonous units of NW lberia: Provenance and paleoposition on the northern margin of Gondwana during the Neoproterozoic and Paleozoic.

Gondwana Res. 18, 385-399.

Díez Fernández, R., Pereira, M.F., Foster, D.A., 2015. Peralkaline and alkaline magmatism of the OssaMorena zone (SW Iberia): Age, source, and implications for the Paleozoic evolution of Gondwanan lithosphere. Lithosphere 7, 73-90.

Díez Fernández, R., Arenas, R., Pereira, M.F., Sánchez Martínez, S., Albert, R., Martín Parra, L.M., Rubio Pascual, F.J., Matas, J., 2016. Tectonic evolution of Variscan Iberia: Gondwana - Laurussia collision revisited. Earth Sci. Rev. 162, 269-292.

Díez Fernández, R., Fuenlabrada, J.M., Chichorro, M., Pereira, M.F., Sánchez-Martínez, S., Silva, J.B., Arenas, R., 2017. Geochemistry and tectonostratigraphy of the basal al- lochthonous units of SW Iberia (Évora Massif, Portugal): keys to the reconstruction of pre-Pangean paleogeography in southern Europe. Lithos 268-271, 285-301.

Díez Fernández, R., Jiménez-Díaz, A., Arenas, R., Pereira, M.F., Fernández-Suárez, J., 2019. Ediacaran obduction of a fore-arc ophiolite in SW Iberia: a turning point in the evolving geodynamic setting of periGondwana. Tectonics. https://doi.org/10.1029/2018TC005224.

Eguíluz, L., 1988. Petrogénesis de rocas ígneas y metamórficas en el Antiforme Burguillos- Monesterio, Macizo Ibérico Meridional. Tesis Doctoral. Universidad del País Vasco, pp. 694.

Fedo, C.M., Nesbitt, H.W., Young, G.M., 1995. Unravelling the effects of potassium me- tasomatism in sedimentary rocks and paleosols, with implications for paleo- weathering conditions and provenance. Geology 23, 921-924.

Fernández-Suárez, J., Díaz García, F., Jeffries, T.E., Arenas, R., Abati, J., 2003. Constraints on the provenance of the uppermost allochthonous terrane of the NW Iberian Massif: 
inferences from detrital zircon U-Pb ages. Terra Nova 15, 138-144.

Fernández-Suárez, J., Arenas, R., Abati, J., Martínez Catalán, J.R., Whitehouse, M.J., Jeffries, T.E., 2007. U-Pb chronometry of polymetamorphic high-pressure granulites: An example from the allochthonous terranes of the NW Iberian Variscan belt. In: Hatcher, R.D. Jr., Carlson, M.P., McBride, J.H. and Martínez Catalán, J.R. (Eds.), 4-D Framework of Continental Crust. Geological Society of America Memoir, vol. 200, pp. 469-488.

Fernández-Suárez, J., Gutiérrez-Alonso, G., Pastor-Galán, D., Hofmann, M., Murphy, J.B., Linnemanm, U., 2014. The Ediacaran-Early Cambrian detrital zircon record of NW Iberia: possible sources and paleogeographic constraints. Int. J. Earth Sci. 103, 1335-1357.

Floyd, P.A., Shail, R., Leveridge, B.E., Franke, W., 1991. Geochemistry and provenance of Rhenohercynian synorogenic sandstones: implications for tectonic environment dis- crimination. Geological Society, London, Special Publications 57, 173-188.

Franke, W., 1989. Tectonostratigraphic units in the Variscan belt of central Europe. In: Dallmeyer, R.D. (Ed.), Terranes in the Circum-Atlantic Paleozoic Orogens. Geological Society of America Special Paper, pp. 67-90.

Fricke, W., 1941. Die Geologie des Grenxebietes zwischen nordöstlicher Sierra Morena und Extremadura. Phd thesis. University of Berlin, Berlin, Germany, pp. 91.

Fuenlabrada, J.M., Arenas, R., Sánchez Martínez, S., Díaz García, F., Castiñeiras, P., 2010. A periGondwanan arc in NW Iberia. I: isotopic and geochemical constraints on the origin of the arc-a sedimentary approach. Gondwana Res. 17, 338-351. 
Fuenlabrada, J.M., Arenas, R., Díez Fernández, R., Sánchez Martínez, S., Abati, J., López Carmona, A., 2012. Sm-Nd isotope geochemistry and tectonic setting of the meta- sedimentary rocks from the basal allochthonous units of NW Iberia (Variscan suture, Galicia). Lithos 148, 196-208.

Fuenlabrada, J.M., Pieren, A.P., Díez Fernández, R., Sánchez Martínez, S., Arenas, R., 2016. Geochemistry of the Ediacaran-Early Cambrian transition in Central Iberia: Tectonic setting and isotopic sources. Tectonophysics 681, 15-30.

Gardien, V., Arnaud, N., Desmurs, L., 2000. Petrology and Ar-Ar dating of granulites from the Galicia Bank (Spain): African craton relics in Western Europe. Geodin. Acta 13, 103-117.

Herron, M.M., 1988. Geochemical classification of terrigenous sands and shales from core or log data. J. Sediment. Petrol. 58, 820-829.

Holland, H.D., 1978. The chemistry of the atmosphere and oceans. Wiley, New York, pp. 351.

IGME, 2014. Mapa geológico de España y Portugal E:1.1000.000. Instituto Geológico y Minero de España, Madrid.

Jacobsen, S.B., Wasserburg, G.J., 1980. Sm-Nd isotopic evolution of chondrites. Earth Planet. Sci. Lett. 50, 139-155.

Lefort, J.P., 1989. Basement correlation across the north Atlantic. Springer-Verlag 148, p. Linnemann, U.,

Romer, R.L., 2002. The Cadomian Orogeny in Saxo-Thuringia, Germany:

geochemical and $\mathrm{Nd}-\mathrm{Sr}-\mathrm{Pb}$ isotopic characterization of marginal basins with con- straints to geotectonic setting and provenance. Tectonophysics 352, 33-64.

Linnemann, U., Pereira, M.F., Jeffries, T., Drost, K., Gerdes, A., 2008. Cadomian Orogeny and the opening of the Rheic Ocean: new insights in the diachrony of geotectonic processes constrained by LAICP-MS U-Pb zircon dating (Ossa-Morena and Saxo- Thuringian Zones, Iberian and Bohemian Massifs). Tectonophysics 461, 21-43.

Linnemann, U., Gerdes, A., Hofmann, M., Marko, L., 2014. The Cadomian Orogen: Neoproterozoic to Early Cambrian crustal growth and orogenic zoning along the periphery of the West African Craton Constraints from U-Pb zircon ages and Hf isotopes (Schwarzburg Antiform, Germany). Precambr. Res. 244, 236-278.

Linnemann, U., Pidal, A.P., Hofmann, M., Drost, K., Quesada, C., Gerdes, A., Marko, L., Gärtner, A., Zieger, J., Ulrich, J., Krause, R., Vickers-Rich, P., Horak, J., 2017. A similar to 565 Ma old glaciation in the Ediacaran of peri-Gondwanan West Africa. Int. J. Earth Sci. 107, 885-911.

Liñán, E., 1984. Los icnofósiles de la Formación Torreárboles (Precámbrico?-Cámbrico) en los alrededores de Fuente de Cantos, Badajoz. Cuadernos del Laboratorio Xeolóxico de Laxe 8, $283-314$.

Lugmair, G.W., Marti, K., 1978. Lunar initial 143Nd/144Nd: differential evolution of the lunar crust and mantle. Earth Planet. Sci. Lett. 39, 349-357.

Lugmair, G.W., Shimamura, T., Lewis, R.S., Anders, E., 1983. Sm-146 in the early solar system evidence from neodymiun in the Allende meteorite. Science 222, 1015-1018.

McCulloch, M.T., Wasserburg, G.J., 1978. Sm-Nd and Rb-Sr chronology of continental crust formation. Science 200, 1003-1011.

McLennan, S.M., Hemming, S.R., 1992. Samarium/Neodymium elemental and isotopic systematics in sedimentary rocks. Geochim. Cosmochim. Acta 56, 887-898.

McLennan, S.M., Taylor, S.R., McCulloch, M.T., Maynard, J.B., 1990. Geochemical and Nd-Srisotopic composition of deep-sea turbidites: crustal evolution and plate tectonic associations. Geochim.

Cosmochim. Acta 54, 2015-2050.

Martín Parra, L.M., González Lodeiro, F., Martínez Poyatos, D., Matas, J., 2006. The Puente GénaveCastelo de Vide Shear Zone (southern Central Iberian Zone, Iberian Massif): geometry, kinematics and regional implications. Bulletin de la Société Géologique de France 177, 191-202.

Martínez Catalán, J.R., 1990. A non-cylindrical model for the northwest Iberian al- lochthonous terranes and their equivalents in the Hercynian belt of Western Europe. Tectonophysics 179, 253-272.

Martínez Catalán, J.R., 2011. Are the oroclines of the Variscan belt related to late Variscan strike-slip tectonics? Terra Nova 23, 241-247.

Martínez Poyatos, D., 2002. Estructura del borde meridional de la Zona Centroibérica y su relación con el contacto entre las Zonas Centroibérica y de Ossa-Morena. Terra Nova 18, 295 p.

Matte, Ph., 2001. The Variscan collage and orogeny (480-290 Ma) and the tectonic de- finition of the Armorica microplate: a review. Terra Nova 13, 122-128. 
Morag, N., Avigad, D., Gerdes, A., Harlavan, Y., 2012. 1000-580 Ma crustal evolution in the northern Aranian-Nubian Shield revealed by U-Pb-Hf of detrital zircons from late Neoproterozoic sediments (Elat area, Israel). Precambr. Res. 208-211, 197-212.

Nakamura, N., 1974. Determination of REE, Ba, Fe, Mg, Na and K in carbonaceous and ordinary chondrites. Geochim. Cosmochim. Acta 38, 757-775.

Nesbitt, H.W., Young, G.M., 1982. Early Proterozoic climates and plate motions inferred from major element chemistry of lutites. Nature 299, 715-717.

Neuman, R.B., Max, M.D., 1989. Penobscottian-Grampian-Finmarkian orogenies as in- dicators of terrane linkages. In: Dallmeyer, R.D. (Ed.), Terranes in the Circum- Atlantic Paleozoic Orogens. Geological Society of America Special Paper, pp. 31-45.

O’Nions, R.K., Carter, S.R., Evensen, N.M., Hamilton, P.J., 1979. Geochemical and cos- mochemical applications of Nd isotope analysis. Annu. Rev. Earth Planet. Sci. 7, 11-38.

Ordóñez Casado, B., 1998. Geochronological studies of the Pre-Mesozoic basement of the Iberian Massif: the Ossa Morena zone and the Allochthonous Complexes within the Central Iberian zone. Phd thesis. Swiss Federal Institute of Technology, Zürich, Switzerland, pp. p.

Ordóñez Casado, B., Gebauer, D., Schäfer, H.J., Gil Ibarguchi, J.I., Peucat, J.J., 2001. A single Devonian subduction event for the HP/HT metamorphism of the Cabo Ortegal complex within the Iberian Massif. Tectonophysics 332, 359-385.

Orejana, D., Martínez, E.M., Villaseca, C., Andersen, T., 2015. Ediacaran-Cambrian pa- leogeography and geodynamic setting of the Central Iberian Zone: constraints from coupled U-Pb-Hf isotopes of detrital zircons. Precambr. Res. 261, 234-251. 
Ovtracht, A., Tamain, G., 1970. Essai tectonique en Sierra Morena (Espagne). Congrès National des Sociétés Savantes. Sciences, Reims. C 95 T1, 305-327.

Pereira, M.F., 2015. Potential sources of Ediacaran strata of Iberia: a review. Geodin. Acta 27, 1-14.

Pereira, M.F., Chichorro, M., Linnemann, U., Eguiluz, L., Silva, J.B., 2006. Inherited arc signature in Ediacaran and Early Cambrian basins of the Ossa-Morena Zone (Iberian Massif, Portugal):

paleogeographic link with European and North African correla- tives. Precambr. Res. 144, 297-315.

Pereira, M.F., Chichorro, M., Solá, A.R., Silva, J.B., Sánchez-García, T., Bellido, F., 2011. Tracing the Cadomian magmatism with detrital/inherited zircon ages by in-situ U-Pb SHRIMP geochronology (OssaMorena Zone, SW Iberian Massif). Lithos 123, 204-217.

Pereira, M.F., Solá, A.R., Chichorro, M., Lopes, L., Gerdes, A., Silva, J.B., 2012. North- Gondwana assembly, break up and paleogeography: $\mathrm{U}-\mathrm{Pb}$ isotope evidence from detrital and igneous zircons of Ediacaran and Cambrian rocks of SW Iberia. Gondwana Res. 22, 866-881.

Pieren, A.P., 2000. Las sucesiones anteordovícicas de la región oriental de la provincia de Badajoz y área contigua de la de Ciudad Real. Universidad Complutense de Madrid, pp. 620 Tesis Doctoral.

Redlin, K., 1955. Stratigraphie und Tektonik der Extremadura im Bereich der Orte Herrera del Duque, Helechosa und Villarta de los Montes (Mittelspanien). PhD. Thesis. Mathem.-Naturw Fakultät, Univ., Münster, pp. 100.

Rodríguez Alonso, M.D., Díez Balda, M.A., Perejón, A., Pieren, A., Liñán, E., López Díaz, F., Moreno, F., Gámez Vintaned, J.A., González Lodeiro, F., Martínez Poyatos, D., Vegas, R., 2004. Dominio del Complejo Esquisto-Grauváquico. Estratigrafía. La se- cuencia litoestratigráfica del NeoproterozoicoCámbrico inferior. In: Vera, J.A. (Ed.), Geología de España. Sociedad Geológica de España-Instituto Geológico y Minero de España, pp. 78-81.

Rodríguez-Alonso, M.D., Peinado, M., López-Plaza, M., Franco, P., Carnicero, A., Gonzálo, J.C., 2004. Neoproterozoic-Cambrian synsedimentary magmatism in the Central Iberian Zone (Spain): geology, petrology and geodynamic significance. Int. J. Earth Sci. 93, 897-920.

Samson, S.D., D'Lemos, R.S., 1998. U-Pb geochronology and Sm-Nd isotopic composition of Proterozoic gneisses, Channel Islands, UK. J. Geol. Soc. 155, 609-618.

San José, M.A., Pieren, A.P., García Hidalgo, F.J., Vilas, L., Herranz, P., Peláez, J.R., Perejón, A., 1990. Central Iberian Zone: ante-Ordovician stratigraphy. In: Dallmeyer, R.D., Martínez García, E. (Eds.), Pre-Mesozoic Geology of Iberia. Springer, pp. 147-159.

Sánchez-García, T., Bellido, F., Quesada, C., 2003. Geodynamic setting and geochemical signatures of Cambrian-Ordovician rift-related igneous rocks (Ossa-Morena Zone, SW Iberia). Tectonophysics 365, 233255.

Sánchez-García, T., Pereira, M.F., Bellido, F., Chichorro, M., Silva, J.B., Valverde- Vaquero, P., Pin, C., Solá, A.R., 2013. Early Cambrian granitoids of North Gondwana 
margin in the transition from a convergent setting to intra-continental rifting (Ossa- Morena Zone, SW Iberia). Int. J. Earth Sci. 103, 1203-1218.

Sánchez-Lorda, M.E., Ábalos, B., García de Madinabeitia, S., Eguiluz, L., Gil Ibarguchi, J.I.,

Paquette, J.L., 2016. Radiometric discrimination of pre-Variscan amphibolites in the Ediacaran Serie Negra (Ossa-Morena Zone, SW Iberia). Tectonophysics 681, 31-45.

Schäfer, H.J., Gebauner, D., Nägler, T.F., Eguiluz, L., 1993. Conventional and ion-mi- croprobe U-Pb dating of detrital zircons of the Tentudia Group (Serie Negra, SW Spain): Implications for zircon systematics, stratigraphy, tectonics and the Precambrian/Cambrian boundary. Contrib. Miner. Petrol. 113, 289-299.

Shaw, J., Gutiérrez-Alonso, G., Johnston, S.T., Pastor-Galán, D., 2014. Provenance variability along the Early Ordovician north Gondwana margin: Paleogeographic and tectonic implications of U-Pb detrital zircon ages from the Armorican Quartzite of the Iberian Variscan belt. Geol. Soc. Am. Bull. 126, 702719.

Stern, R.J., 2002. Crustal evolution in the East African Orogen: a neodymium isotopic perspective. J. Afr. Earth Sc. 34, 109-117.

Talavera, C., Montero, P., Martínez-Poyatoz, D., Williams, I.S., 2012. Ediacaran to Lower Ordovician age for rocks ascribed to the Schist-Graywacke Complex (Iberian Massif, Spain): evidence from detrital zircon SHRIMP U-Pb geochronology. Gondwana Res. 22, 928-942.

Talavera, C., Martínez Poyatos, D., y González Lodeiro, F., 2015. SHRIMP U-Pb geo- chronological constraints on the timing of the intra-Alcudian (Cadomian) angular unconformity in the Central Iberian Zone (Iberian Massif, Spain). Int. J. Earth Sci. (Geol. Rundsch.) 104 (7), 1739-1757.

Taylor, S.R., McLennan, S.M., 1981. The composition and evolution of the continental crust: rare element evidence sedimentary rocks. Philos. Trans. R. Soc. Lond. 3, 3811-3839.

Taylor, S.R., McLennan, S.M., 1985. The Continental Crust: Its Composition and Evolution. Blackwell, Oxford, pp. 312.

Thompson, R.N., 1982. Magmatism of the British Tertiary province. Scott. J. Geol. 18, 49-107.

Ugidos, J.M., Bilström, K., Valladares, M.I., Barba, P., 2003. Geochemistry of the Upper Neoproterozoic and Lower Cambrian siliciclastic rocks and U-Pb dating on detrital zircons in the Central Iberian Zone, Spain. Int. J. Earth Sci. 92, 661-676.

von Raumer, J.F., Stampfli, G.M., 2008. The birth of the Rheic Ocean - Early Palaeozoic subsidence patterns and subsequent tectonic plate scenarios. Tectonophysics 461, 9-20.

von Raumer, J.F., Stampfli, G.M., Arenas, R., Sánchez Martínez, S., 2015. Ediacaran to Cambrian oceanic rocks of the Gondwana margin and their tectonic interpretation. Int. J. Earth Sci. 104, 11071121.

Winchester, J.A., Max, M.D., 1989. Tectonic setting discrimination in clastic sequences: an example from the Late Proterozoic Erris Group, NW Ireland. Precambr. Res. 45, 191-201. 